\title{
LA CRISIS DE LA IDEOLOGÍA PANHISPÁNICA EN IA OBRA DE JOSÉ MARÍA HEREDIA, "LA VISIÓN" (1821): UNA TEMPRANA VERSIÓN DESCONOCIDA DEL POEMA "LAS SOMBRAS" (1825)*
}

Durante su primera estancia en México, entonces aún llamado Nueva España, entre abril de 1819 y febrero de 1821, el joven poeta cubano José María Heredia (1803-1839) entró en la fase más productiva de su labor poética. Aparte de una serie de poesías amatorias y algunos poemas filosófico-descriptivos ${ }^{1}$, en los casi dos años de su permanencia en el Anáhuac, Heredia compuso también varios poemas de índole político-cívica, que se relacionan con acontecimientos históricos concretos de la época. Los alzamientos militares en España a principios de 1820 y el consiguiente reconocimiento de la Constitución de 1812 por Fernando VII, fueron, sin duda alguna, los sucesos políticos que más impresionaron al poeta. $\mathrm{Al}$ conocer "la nueva... tan halagüeña de la restitución del sistema del año 12", como escribió en la única carta conservada a su padre, con fecha de 3 de mayo de $1820^{2}$, Heredia no tardó en emprender una serie de poemas que versan sobre el evento, exaltando a los protagonistas del levantamiento militar como libertadores y a Fernando VII como monarca benigno. Estos poemas son la octava real "1820", la extensa silva "España libre", el "Himno patriótico al restablecimiento de la Constitución", otro "Himno patriótico"-los

* Versión revisada y ampliada de una ponencia presentada en el "Congreso Internacional Homenaje a José María Heredia en su bicentenario (18031839)", que se celebró en el Instituto de Investigaciones Bibliográficas de la Biblioteca Nacional de México, los días 26 a 28 de noviembre de 2003.

${ }^{1}$ Entre ellos figuran los "Fragmentos descriptivos de un poema mexicano" (ed. de 1825), posteriormente difundidos bajo el título más conocido de "En el teocalli de Cholula" (ed. de 1832).

2 José María Heredia, Prédicas de libertad, Secretaría de Educación, La Habana, 1936, pp. 41 ss. 
cuatro publicados ese mismo año en México y Cuba, respectivamente- así como la canción fúnebre titulada "El dos de mayo", que vio la luz pública en México hacia finales de 1821, es decir, después del regreso de Heredia a La Habana.

Tanto en estos poemas como en la carta citada, no cabe la menor duda de que Heredia considera a España como patria y que su posición ideológica, inequívocamente pro-ibérica, presupone todavía la unidad del mundo hispánico bajo la corona de Fernando $\mathrm{VII}^{3}$. Al igual que en varios otros poemas escritos hasta ese momento ${ }^{4}$, Heredia toma partido a favor de la causa española en la Península y en el continente americano. Así, también en la América hispánica, los héroes son todavía los españoles o los criollos que logran instaurar la paz en medio del desorden de las luchas independentistas. Como es sabido, Heredia se distanciará pronto de esta perspectiva, dando expresión en varias poesías a una conciencia plenamente hispanoamericana. Como consecuencia de este giro ideológico ninguno de los poemas hasta aquí mencionados se hallará en las ediciones de las poesías de Nueva York (1825) y Toluca (1832), preparadas por el propio autor. Si bien no cabe la menor duda de la reorientación ideológica del joven poeta en sí, la transición desde una actitud afirmativa ante España y los representantes del poder colonial en la América española, hacia una actitud abiertamente antiespañola, merece un comentario más detenido.

A continuación, me propongo demostrar que el poema "La visión", una temprana versión de "Las sombras", publicada de forma anónima en México a finales de $1821^{5}$, marca en la poe-

3 Salvador Arias observa que en "España libre" "[f]rente a la "patria" hispánica, un tanto abstracta e idealizada, se va concretando otra, «mi patria», el suelo que lo viera nacer, como acota muy claramente" ("La obra literaria de José María Heredia", Historia de la literatura cubana, t. 1: La colonia: Desde los ońgenes hasta 1898, Letras Cubanas, La Habana, 2002, p. 129). Sin embargo, es importante ver que este matiz, que parece anticipar el patriotismo cubano de años posteriores, no rompe todavía con la idea de la unidad del imperio hispánico.

${ }^{4}$ En este sentido véase también el soneto titulado "A la muerte de la Reina Nuestra Señora Doña María Isabel Francisca [de Braganza]" (¿1819?), la segunda esposa de Fernando VII, muerta en 1818, la "Oda sobre la pacificación de Nueva España, dirigida al coronel D. José Barradas" (1819), el himno "En celebración de las victorias conseguidas en Nueva España bajo el gobierno del Excmo. Sr. Conde del Venadito" (¿1820?) y el himno “A la paz" (1820).

5 Véase el Apéndice para un cuadro sinóptico que reproduce las tres versiones conocidas de este poema y los correspondientes datos bibliográficos. 
sía herediana un paso decisivo hacia una toma de conciencia de la condición americana como lo propio en oposición a lo ajeno de procedencia española. Con ello es posible relacionar, con mayor seguridad, la crisis de la ideología panhispánica de Heredia con su primera estancia en México y delimitar con bastante precisión el lapso en el cual aquella crisis se manifiesta en su obra poética ${ }^{6}$.

Los poemas heredianos escritos a propósito de algún acontecimiento concreto de dimensiones cívicas destacan no sólo por su común actitud conciliadora a partir de un fundamento ideológico panhispánico, sino que algunos de ellos coinciden además en enfocar el respectivo suceso en un momento posterior a su desenlace feliz. En varias composiciones esta circunstancia queda señalada ya en el título ${ }^{7}$. Así, Heredia no formula sus invectivas contra la tiranía sino en un momento en que ésta parece haber cedido ante la paz, o bien, después de la destitución del tirano imprecado. En otras palabras, en esta primera fase de su producción poética, Heredia se apropia de la realidad conflictiva del momento histórico que le ha tocado vivir desde un punto de vista que le permite, en última instancia, mantener intacta su visión armónica del imperio hispánico.

La poesía aparece como escenario para la representación de un pequeño drama histórico. En "A la paz" y en "España libre", por ejemplo, el hablante lírico evoca su sufrimiento ante los horrores de la tiranía, guiando al lector por una serie de momentos sucesivos de una cadena de acontecimientos y los correspondientes estados anímicos, cada uno de ellos evocado con una mínima distancia afectiva, hasta el final feliz en el que el conflicto queda resuelto. Resulta que esta manera de apropiarse de la realidad política de la época a partir del ideal de una convivencia pacífica entre españoles y criollos, en cuyo marco la tiranía aparece como aberración temporal, implica,

\footnotetext{
${ }^{6}$ Por otra parte, el hecho de que "La visión" se publicó primero en 1821 invita a reconsiderar la posibilidad de que Olmedo se inspirara para su oda "La victoria de Junín. Canto a Bolívar" (1825) en este poema; posibilidad que Manuel Pedro González no puede sino descartar ("Una influencia inexplorada en Ignacio Rodríguez Galván”, CuA, 84, 1955, p. 276).

7 Véanse en este sentido, por ejemplo, los poemas "Oda sobre la pacificación de Nueva España, dirigida al coronel D. José Barradas" (1819), "En celebración de las victorias conseguidas en Nueva España bajo el gobierno del Excmo. Sr. Conde del Venadito" (¿1820?) y el himno "A la paz" (1820).
} 
en última instancia, la exclusión sistemática del universo poético herediano, de los numerosos conflictos irresueltos.

El patriotismo panhispánico de Heredia y la correspondiente visión armónica se manifiestan por última vez y de manera enfática a propósito de la restauración de la Constitución de 1812, con la cual comienza en España el breve lapso constitucional que se conocerá como trienio liberal. Sin embargo, ya algunos meses antes, en la oda "Al Popocatépetl", publicada en México en enero de $1820^{8}$, la realidad americana irrumpe en la poesía herediana, aunque de forma ideológicamente ofensiva. En este texto, a partir de la contemplación del inmenso volcán - primera manifestación de la exaltación ante un fenómeno sublime de la naturaleza americana en la obra herediana9-, el hablante lírico evoca de manera sinecdóquica al "fiero tlascalteca" (v. 23) y al "español osado" (v. 163) ${ }^{10}$, esbozando una visión histórica de su respectiva actitud ante el poderoso volcán. En ella, la intrepidez de los conquistadores españoles, que desafían al Popocatépetl subiéndolo hasta la cumbre ${ }^{11}$ contrasta radicalmente con el temor al volcán y su veneración por parte de los habitantes primitivos ${ }^{12}$, si bien ambos grupos en ningún momento a lo largo del poema llegan a relacionarse entre ellos $^{13}$. Mientras que la visión positiva de los españoles, repre-

8 Cf. Francisco González del Valle, Cronología herediana (1803-1839), Dirección de Cultura, La Habana, 1938, p. 92.

${ }^{9}$ Cf. Tilmann Altenberg, Melancolia en la poesía de José María Heredia, Vervuert-Iberoamericana, Frankfurt/M.-Madrid, 2001, pp. 236 ss.

10 Salvo en los casos expresamente señalados, todas las citas textuales de la obra herediana corresponden la Obra poética herediana de 1993 (ed. A. Augier, Letras Cubanas, La Habana), refundición de las Poesías completas en dos tomos de 1940-1941.

11 "Mira tu faz el español osado / Y temerario intenta / Penetrar tus misterios escondidos" (vv. 163 ss.). Para un minucioso estudio de las fuentes de Heredia así como el carácter fundacional de este poema véase María C. Atbín, "Mito e historia en la poesía de José María Heredia", Hispanófila, 2002, núm. 135, 89-106.

12 "Mil torrentes de fuego vomitabas, / Y el fiero tlascalteca / El ímpetu temiendo de tus lavas, / Ante tu faz postrado / Imploraba lloroso tu clemencia!" (vv. 22-26).

13 Tal vez no sea fortuito que entre los pueblos mexicanos autóctonos de la región, Heredia eligiera a los tlaxcaltecas, porque el hecho histórico de su lealtad a los conquistadores españoles en su pugna contra los aztecas evita que el cuadro estéticamente "puro" de la lucha del hombre con el volcán adquiera el tinte poco sublime de una discordia entre ambos grupos mencionados. 
sentados aquí de manera favorable en un momento temprano de su presencia en el continente americano, permanece pues, intacta, la evocación de los tlaxcaltecas se reduce a un elemento circunstancial cuya función no parece trascender las necesidades inmediatas de ambientación y de la construcción simétrica de la oda.

De manera parecida, también en los "Fragmentos descriptivos", compuestos, según las indicaciones del propio Heredia, en diciembre de 1820 , la evocación de los "aztecas valientes" (v. 2) al principio del primer fragmento contribuye a ambientar la descripción de la exuberante naturaleza mexicana ${ }^{14}$. Sin embargo, en la subsiguiente meditación acerca de la grandeza de los volcanes mexicanos y su impasibilidad ante el poder arrasador del tiempo, que contrasta con la fugacidad de toda empresa humana -tópico predilecto de la poesía neoclásica-se hallan dos pasajes que remiten de manera bastante difusa a la situación contemporánea de la Nueva España en vísperas de su independencia.

Primero, cuando Heredia afirma "que en medio de estos campos reina alzada / la bárbara opresión..." (vv. 47 ss.), es plausible leer este uso del presente no como actualización de una supuesta tiranía ejercida en un pasado histórico por los reyes aztecas - tema que sólo entrará en la versión definitiva publicada en la edición de Toluca $(1832)^{15}$-, sino como censura

${ }^{14}$ Para ANDRÉs Bello, quien figura entre los primeros recensores de las Poesias heredianas de 1825; como se sabe, estos "Fragmentos" destacan por su particular "nobleza y elevación" (Temas de crítica literaria, Ministerio de Educación, Caracas, 1956, p. 238). En vista del parecido entre la silva "La agricultura de la zona tórrida", publicada en 1826, y los "Fragmentos" heredianos, es posible que Bello se dejara inspirar por los versos del joven cubano. Véanse al respecto T. AltenberG, op. cit., pp. 154 ss., y n. 201, y M. C. Albín, art. cit., p. 93.

${ }^{15} \mathrm{Es}$, sin duda, a esta última versión a la que se refiere MARY Louise PRATT cuando observa -siempre refiriéndose a "En el teocalli de Cholula", cuya composición supone erróneamente de 1820 - que "Spanish tyranny is equated with what for Heredia was Aztec barbarism" (Imperial eyes: Travel writing and transculturation, Routledge, London, 1992, p. 182). No es ésta la única imprecisión de la autora respecto de Heredia. Así, vincula la estancia de Heredia en México en 1820 por error con "his independentista activities" en Cuba (las cursivas son del original). Por otra parte, la aparente inconsecuencia de Heredia en el momento de juzgar moralmente el régimen azteca no sólo revela el carácter instrumental de aquel imperio para los fines de la respectiva composición, sino que corresponde también a cierta ambivalencia en el pensamiento político de principios del siglo xix. Así, mientras 
a las sangrientas luchas fraticidas en el suelo mexicano ${ }^{16}$. Sin embargo, en este pasaje no queda claro quiénes son, en el concepto de Heredia, los opresores ${ }^{17}$. Más adelante, en un apóstrofe dirigido al Popocatépetl, que vincula los "Fragmentos descriptivos" con el homónimo poema antes mencionado ("Al Popocatépetl") ${ }^{18}$, el poeta no deja lugar a duda de que concibe la lucha contra la opresión también como suya, incluyéndose explícitamente entre los combatientes: "...Pueblos y reyes / viste hervir a tus pies, que combatían / cual hora combatimos..." (vv. 84 ss.). Es así como en los "Fragmentos descriptivos", a diferencia de aquellos poemas cívicos anteriores de Heredia en donde se evoca una secuencia de acontecimientos del pasado inmediato desde la perspectiva de su desenlace feliz, asoma por primera vez en la poesía herediana un conflicto contemporáneo cuya solución estaba pendiente.

La indeterminación en el momento de identificar los bandos del conflicto y adscribir los papeles desempeñados en él, no se debe, a mi entender, ni primera ni exclusivamente al carácter secundario-funcional del tema en el marco de la composición. Antes bien, se explica esencialmente por otro motivo de mayor envergadura. La compleja situación política en la Nueva España en vísperas de la Independencia, presenciada de cerca por el joven Heredia, no se prestaba a la misma reducción maniquea que, por ejemplo, los acontecimientos aislados de la momentánea restitución de la paz por el virrey Apodaca o el restablecimiento de la Constitución por Fernando VII. Visto así, es plausible suponer que Heredia, para quien durante tantos años la legitimidad y dignidad del gobierno colonial habían estado fuera de duda, en medio de las convulsiones políticas no veía muy claro cómo conciliar la realidad experimentada

que, por un lado, se enfatizaba la continuidad entre un futuro imperio mexicano -sea república, sea monarquía - con el imperio de los aztecas; por el otro, el gobierno azteca se consideraba un sistema despótico que sería preciso mejorar (cf. RAFAel RojAS, "El México de Iturbide: indicios de un imaginario imperial", Política y Gobierno, 6, 1999, pp. 484 ss.).

16 Cf. SAlvador ARIAS, "Nuestro primer gran poema. (Estudio de «En el teocalli de Cholula» de José María Heredia)", Büsqueda y análisis. Ensayos criticos sobre la literatura cubana, Unión, La Habana, 1974, pp. 26 ss.

${ }^{17}$ En este punto me aparto de la lectura hecha por S. ARIAS, art. cit.

18 M. C. Albín va aún más lejos proponiendo leer ambas composiciones "como un mismo poema, siendo el texto posterior un ampliación y desarrollo del primero" (art. cit., p. 96). 
con ese su bagaje ideológico. De ahí que evitara declararse con mayor claridad y se atuviera a las abstracciones, denunciando la bárbara opresión sin identificar a sus autores. Los "Fragmentos descriptivos" sugieren que poco después de la muerte de su padre los fundamentos ideológicos de Heredia entraron en crisis. Sin embargo, este primer paso tímido hacia una apropiación más inmediata de los conflictos hispanoamericanos que le rodeaban no implica todavía, ni mucho menos, una posición antiespañola.

En un tercer poema de la misma época, que por la situación de enunciación del hablante lírico y su actitud meditativa bajo el influjo de un escenario concreto de la realidad mexicana se relaciona estrechamente con "Al Popocatépetl" y los "Fragmentos descriptivos", Heredia da otro paso decisivo en la dirección de tomar conciencia de su condición hispanoamericana. Se trata de la silva "La visión", escrita probablemente en 1821, tal vez aun antes del regreso de Heredia a Cuba, y publicada de forma anónima en México, en diciembre del mismo año ${ }^{19}$.

En los 331 versos de este poema, Heredia desarrolla el tópico del $u b i$ sunt $^{20}$ a propósito de la desaparición del imperio azteca ${ }^{21}$.

${ }^{19}$ En otro lugar (T. Altenberg, op. cit., p. 109, n. 143) di cuenta del hallazgo de "La visión" ( $\sin$ reproducir el texto), poema no documentado hasta ese momento por la crítica. Esta circunstancia se debe, sin duda, al anonimato de la primera publicación. Posteriormente a su primera publicación en 1821, "La visión" se volvió a publicar en dos versiones bastante retocadas en México, en 1825, y en la edición neoyorquina de las poesías heredianas, en 1875, respectivamente, bajo el título de "Las sombras".

${ }^{20} \mathrm{~J}$. S. Cunningham, en un interesante estudio acerca de las diferentes formas del ubi sunt en la literatura occidental, a propósito de Wordsworth llama la atención sobre "the paradox that in the moment when what is lost is fully conceived, it is repossessed" ("Warton lecture: «Where are they?": The after-life of a figure of speech", Proceedings of the British Academy, 65, 1979, p. 376). También en Heredia la retórica del ubi sunt se une a la actitud meditativo-evocativa del hablante lírico respecto de un pasado glorioso perdido. Por otra parte, es interesante observar que en el inédito Catálogo de los libros que forman la biblioteca particular de D. José Maria Heredia (41 hojas manuscritas, C. M. Heredia Cat., Biblioteca Nacional José Martí, La Habana), confeccionado por el propio poeta en 1833, figuren también ediciones de los Night thoughts, de Edward Young, y de The grave, de Robert Blair, dos textos en los cuales abundan las reflexiones sobre la muerte y que hacen también eco del ubi sunt.

${ }^{21}$ Véase R. Rojas, art. cit., pp. 482 ss., para algunas observaciones fundamentales acerca de la visión del imperio azteca como modelo para un nuevo imperio mexicano, en el pensamiento político de la época. 
El hablante lírico evoca una noche en la cual erraba meditabundo por Chapultepec cuando a modo de visión aparecían ante sus ojos las figuras de los tres últimos reyes aztecas, Moctezuma, Cuitláhuac y Guatimozín. A lo largo de 200 versos, aproximadamente, el hablante lírico delega la voz a los soberanos americanos, quienes invocan, a su vez, a otros monarcas del sur de América. Todos ellos coinciden en lamentar la destrucción de sus reinos, aunque no están de acuerdo acerca de su respectivo papel en la lucha contra los conquistadores españoles, calificados de "hombres bárbaros, feroces" (v. 177) ${ }^{22}$.

Lo que salta a la vista en este poema es, en primer lugar, la insistencia y severidad de la crítica antiespañola, que se manifiesta en dos planos: en las palabras del propio hablante lírico y en las lamentaciones de los soberanos americanos ${ }^{23}$. Ya en los versos introductorios, donde se fijan el eje tópico y el marco meditativo de la composición, el hablante lírico se pronuncia acerca de los españoles declarando de forma apodíctica que:

$$
\begin{aligned}
& \text { Cualesquiera extranjero es un tirano } \\
& \text { que orgulloso y feroz sin más derecho } \\
& \text { que nacer en Canarias o en Europa } \\
& \text { al débil criollo con soberbia mano } \\
& \text { maltrata, insulta, oprime } \\
& \text { (vv. 39-43). }
\end{aligned}
$$

Esta oposición entre el extranjero y el criollo es particularmente significativa porque parece estar fuera de lugar en un contexto en el cual el hablante lírico acaba de llamar la atención sobre la discrepancia entre la grandeza de los antiguos

22 En 1819 Heredia emprendió la composición (¿traducción?) de una tragedia titulada Moctezuma, proyecto que abandonó antes de concluir el segundo acto (cf. Francisco González del VAlLE, Cronología herediana [18031839], Dirección de Cultura, La Habana, 1938, p. 80). Sería de sumo interés cotejar "La visión" con ese drama. Aparte de la evidente coincidencia temática, en vista del carácter dramático de la evocación de los soberanos americanos en el poema, parece lógico suponer que Heredia utilizara pasajes de la tragedia inconclusa en el momento de componer el poema. Infelizmente, no está claro en qué biblioteca o archivo se encuentra actualmente el manuscrito inédito de Moctezuma.

${ }^{23}$ Para M. P. González, "la agresiva y desdeñosa actitud hacia los conquistadores y hacia España que Heredia reitera a lo largo del poema" es responsable del "severo desdén" con que Menéndez y Pelayojuzgó la segunda versión de este poema, de 1825 (art. cit., p. 269). 
reinos americanos y la mísera condición de los indígenas contemporáneos "desde que la opresión y tiranía / aquí sentaron su nefando trono" (vv. 37-38). Sin duda alguna, hubiera sido más coherente enfocar el sufrimiento del indio y no del criollo.

Es interesante notar que, en un momento posterior, el propio Heredia sustituyera, efectivamente, criollo por indio, y extranjero por español, cambiando así considerablemente el significado del pasaje. En la versión primitiva los versos citados sugieren una correspondencia entre la situación de los criollos y la de los indígenas y, con ello, una continuidad histórica de la opresión y tiranía en la América hispánica, que arranca de las atrocidades cometidas por los conquistadores españoles y continúa hasta el presente de la enunciación en el poema, afectando del mismo modo a indígenas y criollos. En las versiones posteriores, sin embargo, si bien el pasaje citado gana en coherencia, la indignación del hablante lírico ante la opresión española de los indígenas apenas trasciende de un indigenismo criollo conforme al prototipo discursivo del indio flemático y triste ${ }^{24}$ en el marco de una meditación filosófico-histórica de corte neoclásico ${ }^{25}$.

$\mathrm{Al}$ contraponer en "La visión" criollos y extranjeros, que extensionalmente apuntan a los españoles, Heredia formula por primera vez en su poesía una posición inequívocamente americana. Lo propio no se integra más en lo panhispánico-concepto que, como hemos visto, hasta ese momento sostenía el pensamiento cívico y el universo poético heredianos-, sino que termina en el lado americano del océano Atlántico ${ }^{26}$. Esta toma de conciencia por parte de Heredia de su propia condición americana se basa, en "La visión", esencialmente en una alianza ad

24 Cf. José Antonio Mazzotti, "Indigenismos de ayer: prototipos perdurables del discurso criollo", Indigenismos hacia el fin del milenio: Homenaje a Antonio Comejo-Polar, ed. M. Moraña, University of Pittsburgh, Pittsburgh, 1998, pp. 91 ss.

25 No olvidemos que estructuralmente el poema se inspira, antes que en una experiencia vivencial concreta, en la silva "El Panteón del Escorial" (1805), de Manuel José Quintana, como han notado, entre otros, MARCELIno Menéndez y Pelayo (Historia de la poesia hispano-americana, Victoriano Suárez, Madrid, 191 1, t. 1, p. 235) y Manuel Pedro González (José Maria Heredia, primogénito del romanticismo hispano. Ensayo de rectificación histórica, El Colegio de México, México, 1955, pp. 133-137); cf. S. ARIAS, "Nuestro primer gran poema”, p. 21, n. 14.

${ }^{26}$ Posteriormente, en su famoso "Himno del desterrado" (1825), Heredia es más explícito al respecto cuando concluye señalando "Que no en vano entre Cuba y España / Tiende inmenso sus olas el mar" (vv. 111 ss.). 
hoc, que podríamos calificar de estratégica, con la causa indígena. En esta construcción, la condena de los españoles no se desprende de un análisis de la situación de los criollos, sino de las atrocidades cometidas por los primeros conquistadores. Así, son los soberanos americanos quienes "con rabia dolorosa" (v. 99) detallan la conducta de los españoles llamándolos, entre otras cosas, "asesinos" (v. 110), "crueles opresores" (v. 145) y "tiranos" (v. 240).

Hacia el final del poema, en un pasaje suprimido en las versiones posteriores - probablemente porque rompe el esquema predominante hasta ese momento, según el cual se evocan las víctimas de la opresión española y no sus autores-el "bárbaro Cortés" (v. 302) penetra la visión del hablante lírico escuchando la invectiva de Moctezuma. Al concluir éste su lamentación, aquél se enternece y "...triste sintiendo / remordimientos mil, su faz odiosa / entre las manos escondió..." (vv. 302 ss.). Si la desconcertante reacción del caudillo español indica la fuerza conmovedora de las palabras de su víctima y, con ello, la dimensión de las atrocidades por él cometidas, con el subsiguiente apóstrofe del hablante lírico como "Joven sensible" (v. 307), en boca de Moctezuma, nos encontramos ante un ideologema clave de la época y de la autorrepresentación poética de Heredia; porque el hablante lírico, cuya construcción autobiográfica remite al propio poeta, no sólo se emociona ante las desgracias presenciadas, como testimonian los sollozos y las lágrimas derramadas bajo el efecto de las palabras de Moctezuma ${ }^{27}$. Su capacidad de ver y objetivar poéticamente visiones, de las que nos hace participar en el poema en cuestión, entre otros, sugiere también la superioridad de su sensibilidad poética sobre la de un hombre sensible común ${ }^{28}$.

En su apóstrofe, Moctezuma exhorta al joven sensible a contemplar los crímenes de los españoles y los efectos de su codicia: "de tus padres los crímenes contempla. / De su ambición,

27 "...mi tierno pecho comprimido / en sollozos rompió: mi ardiente rostro / un torrente de lágrimas bañaba" (vv. 321 ss.).

${ }^{28}$ En esta particular disposición se sobreponen la clásica concepción del poeta como vidente inspirado (poeta vates) y la idea del sujeto poético como genio, dotado de una capacidad creativa que excede el mero talento (cfi T. AltenberG, op. cit., pp. 225-232). El llanto del hablante lírico bajo el efecto de la visión, además de confirmar su condición de poeta sensible, tiene un cariz catártico. Delante de tan impresionante muestra de la ferocidad de los españoles, le será imposible volver a defender su causa en América. 
de su codicia horrible / los efectos he aquí..." (wv. 308 ss.). En este pasaje, donde una sola vez un soberano de la visión toma noticia del poeta que los está observando, la calificación de los conquistadores como padres del joven sensible en boca de una de sus víctimas, alberga un claro llamamiento a distanciarse de ellos. Es así como, por su condición privilegiada de vidente sensible, el poeta parece contraer un compromiso con el cual ya ha cumplido en el propio poema, antes de poner en escena la visión en Chapultepec, en el momento de tildar a los extranjeros de tiranos.

Un poco más adelante, en otro apóstrofe, dirigido a los monarcas congregados, Moctezuma señala el carácter ejemplar de su suerte y concluye: “...si un extranjero / disimulado intenta dominaros, / si queréis en el trono aseguraros, / tiña su negra sangre vuestro acero" (vv. 317-320). En el contexto inmediato, esta lección histórica resulta una abstracción sin consecuencia alguna, puesto que la caída de los monarcas apostrofados y la desaparición de sus reinos son hechos consumados, también desde el punto de vista de los propios soberanos. Si bien es cierto que este tipo de generalización didáctica es una constante en la poesía herediana que está muy en la línea del Neoclasicismo, visto el poema en su conjunto, en un segundo plano de sentido, la amonestación parece trascender la situación de comunicación intratextual, apelando indirectamente a los americanos contemporáneos del poeta a defender la libertad contra cualquier intento de dominación extranjera ${ }^{29}$.

Resulta que la introducción de voces ajenas en un segundo plano de enunciación lleva en este "poema dramático"30 a cierta interferencia de las diversas perspectivas históricas e ideológicas. Aparte del logro estético que significa delegar la voz a los príncipes americanos para dejar que ellos hablen de sus propias vivencias, al superponer las voces de los soberanos americanos a las palabras del hablante lírico, Heredia parece atenuar hasta cierto punto su propia posición antiespañola. Al mismo tiempo, sin embargo, las sombras de los héroes no hacen sino

${ }^{29}$ Las palabras que preceden la publicación de "Las sombras" en la $G a$ ceta diaria de México, el 23 de octubre de 1825 (pp. 2-4), confirman esta lectura. En ese primer documento de recepción del poema se le califica a Heredia como "poeta de la libertad del nuevo mundo" (p. 2).

${ }^{30}$ Alejandro González Acosta, "Dos actitudes en la visión del paisaje histórico: José María Heredia e Ignacio Rodríguez Galván. Una lectura paralela", El Centavo, noviembre de 1993, p. 6. 
confirmar desde un punto de vista ajeno, aunque sí americano, el juicio categórico acerca del carácter tiránico de los españoles, formado por el hablante lírico antes de evocar la visión. De ahí que el aparente plurilingüismo en "La visión" no corresponda a una efectiva diversidad de puntos de vista en el sentido bajtiniano, sino que su orientación ideológica resulta ser centrípeta antes que centrífuga ${ }^{31}$. Visto así, Heredia parece citar a los soberanos como testigos en una causa contra la tiranía española en América, alegando como argumento principal la continuidad histórica de la crueldad de los españoles desde los primeros momentos de su presencia en el continente ${ }^{32}$. El aparente indigenismo de Heredia en este poema es meramente retórico-funcional y no ofrece, obviamente, una auténtica visión de los vencidos en el sentido acuñado por León-Portilla hace casi medio siglo ${ }^{33}$.

En el contexto de la pequeña secuencia de poemas aquí considerados, "La visión", escrito con toda probabilidad después de los "Fragmentos descriptivos", representa un momento en el cual el joven poeta ha tomado conciencia de su condición criolla y del carácter ilusorio de sus esperanzas de paz y libertad en el hemisferio americano bajo la tutela de España. El que este desplazamiento ideológico se manifieste primero en poemas de índole filosófico-descriptiva y en un plano más bien secundario, sugiere que no estamos ante los efectos de una espontánea revelación, sino ante un proceso gradual y difícil, aunque relativamente rápido.

Mientras que en "Al Popocatépetl" la contemplación del hablante lírico bajo los efectos de un escenario concreto parece coincidir con el momento de enunciación, en los "Fragmentos descriptivos" y en "La visión", Heredia hace evocar, al hablante

${ }^{31}$ Para Mijall Bajtín, es ésta una característica genérica de la poesía stricto sensu: "El lenguaje del género poético es un universo ptoloméico unitario y único, fuera del cual no existe nada y no se necesita nada. La idea de la pluralidad de los universos lingüísticos, igualmente significativos y expresivos, es orgánicamente inalcanzable para el estilo poético" (Teoría y estética de la novela, Taurus, Madrid, 1991, p. 103).

${ }^{32}$ A. González Acosta ve en este fenómeno "una muy peculiar interpretación de la historia por parte del poeta, que la maneja de forma personal, pues lo verdaderamente interesante no es la historia pasada, sino la asociación -y el manejo- que pueda hacerse de aquélla para el presente" (art. cit., p. 6).

33 Cf. Miguel León-Portilla, La visión de los vencidos. Relaciones indígenas de la Conquista [1959], 13ª ed., rev. y enriquecida, UNAM, México, 1992. 
lírico, una escena en el pasado, transponiendo así la respectiva meditación en un segundo plano. Esta escisión del hablante lírico en un sujjeto que recuerda y un sujeto recordado, que presupone un alto grado de conciencia de sí mismo, puede leerse como representación, en el plano textual, de la toma de conciencia, por parte del poeta, de su propia condición. Con esta construcción parece que, como lectores, en "La visión" presenciamos el proceso que llevará a Heredia, en última instancia, a sostener un ferviente americanismo, que puede prescindir de este tipo de ejercicio autoafirmativo.

Si aceptamos el diagnóstico que acabo de exponer, se impone la pregunta de cómo se explica que a los pocos meses de celebrar con entusiasmo el restablecimiento de la Constitución de 1812 y exaltar a Fernando VII como monarca benigno, la ideología panhispánica de Heredia entre en crisis y ceda ante una actitud inequívocamente antiespañola. Para responder a este interrogante es inevitable recurrir a circunstancias extraliterarias.

Un factor decisivo en el proceso esbozado fue, sin duda, la muerte de José Francisco Heredia, ocurrida el 31 de octubre de 1820. Existen muchos indicios de que el padre era para el poeta una figura intachable, casi sagrada, que representaba los ideales de libertad y justicia en el marco del sistema colonial ${ }^{34}$. Es posible que con la muerte del padre, que significó también el cese de los vínculos directos de la familia Heredia con el gobierno del virreinato, José María se permitiera por primera vez en su vida dudar de la intangibilidad de la ideología panhispánica. Por otra parte, en México, el hijo vivió en su propia piel la intransigencia de las autoridades españolas. Así, la solicitud presentada por José Francisco Heredia cinco meses antes de su fallecimiento, con el fin de lograr la dispensa de un curso académico para su hijo José María, fue rechazada ${ }^{35}$. Del mismo modo, otra solicitud hecha por el propio hijo con el mismo fin pocas semanas después de la muerte de su padre, alegando la precaria situación económica de la familia así como "los distin-

${ }^{34}$ Parece que a pesar de los contratiempos sufridos por el funcionario en el ejercicio de sus cargos en Venezuela, éste nunca dejó de considerarse como defensor de los justos y legítimos intereses de la corona española en América (cf. José María Chacón y Calvo, Criticismo y libertad: Euocación de José Francisco Heredia, Regente de Caracas, Secretaría de Educación, La Habana, 1939 , p. 40).

35 Cf. Manuel García Garófalo Mesa, Vida de José María Heredia en México 1825-1839, Botas, México, 1945, p. 68. 
guidos servicios" de José Francisco Heredia ${ }^{36}$, no llegó a despacharse a tiempo a causa del regreso de la familia Heredia a La Habana, a principios de febrero de 1821. Me parece plausible suponer que esta serie de disgustos contribuyó a inclinar a Heredia al ideario independentista.

Por otra parte, hay que tener en cuenta que probablemente ya antes de su traslado a la Nueva España, todavía en Cuba, Heredia había frecuentado a un grupo de hispanoamericanos residentes en La Habana, llegando a trabar amistad con Vicente Rocafuerte, José Antonio Miralla y José Fernández Madrid ${ }^{37}$, "portavoces de las ideas revolucionarias de las guerras por la independencia de América"38. A través de este contacto Heredia estaría, pues, familiarizado con el ideario independentista, aunque en ese momento su formación y tutela paterna impidieran todavía que se identificase con él. Si recordamos, por último, el ambiente general en la Nueva España en vísperas de su independencia, con la mayoría de los españoles y criollos, ajenos al gobierno colonial, cada vez más ansiosos de ver triunfar el movimiento independentista ${ }^{39}$, no debe sorprender que el andamiaje ideológico del joven poeta entrara en crisis para admitir elementos heterodoxos que, con toda probabilidad, habrían escandalizado a su padre.

Para resumir, sean cuales fueren los motivos concretos del giro ideológico esbozado, los indicios textuales son suficientemente claros para permitir fijar los últimos meses de la primera estancia mexicana de Heredia, que preceden inmediatamente a la consumación de la independencia del país que más adelante se convertirá en su segunda patria, como punto de arranque de una crisis de su pensamiento panhispánico. Sin embargo, cabe señalar que ni en ese lapso ni posteriormente el poeta llegará a poner en tela de juicio los fundamentos de su ideario cívico. Así, en ningún momento cesan la exaltación por la libertad y el desprecio hacia la tiranía, aunque los términos sí sufren una reorganización, mudando de referente conforme a la situación concreta evocada.

${ }^{36}$ Cit. en ibid., p. 113.

${ }^{37}$ Cf. SAlvador Arias, "La obra literaria de José María Heredia", p. 128.

38 Marta Lesmes, "Hispanoamericanos emigrados en Cuba", Historia de la literatura cubana, t. 1: La colonia..., p. 106.

${ }^{39}$ Cf. M. García Garófalo Mesa, op. cit., p. 63. 
La "Oda a los habitantes de Anáhuac", por ejemplo, escrita a propósito de la autoproclamación de Iturbide como Emperador de México en marzo de 1822, revela esta nueva flexibilidad del pensamiento cívico en Heredia. Cada vez más atento a los conflictos irresueltos en el continente americano, el poeta ya no defiende la libertad contra los extranjeros, sino contra la tiranía de un usurpador americano en un país independiente. Y en el conocido himno "La estrella de Cuba", de octubre de 1823, primera muestra poética del flamante patriotismo cubano en Heredia, los traidores y tiranos son, otra vez, los españoles.

Tilmann Altenberg

Universität Hamburg 


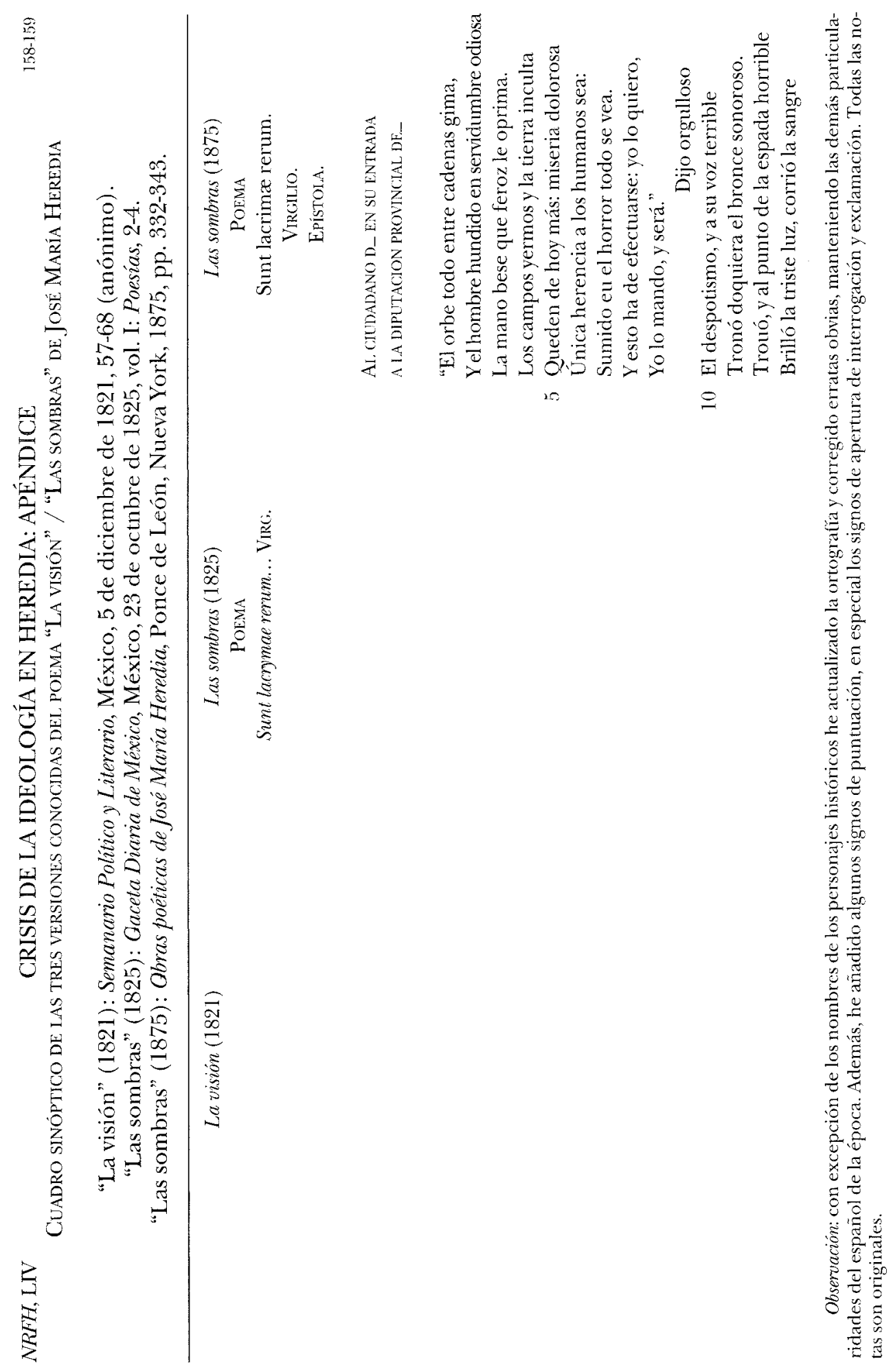




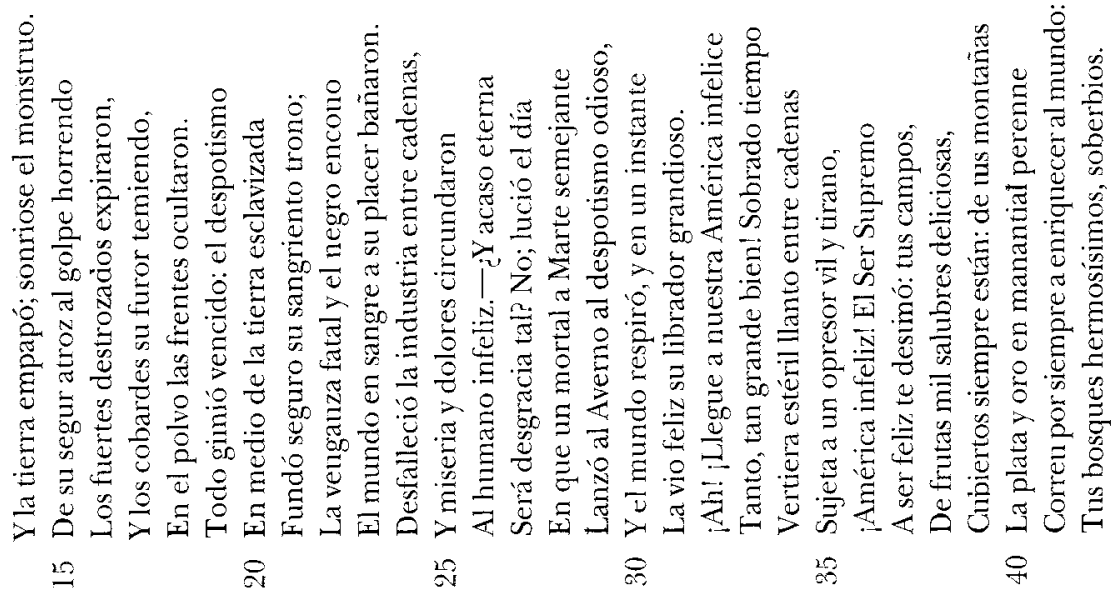


$\stackrel{0}{\frac{0}{0}}$

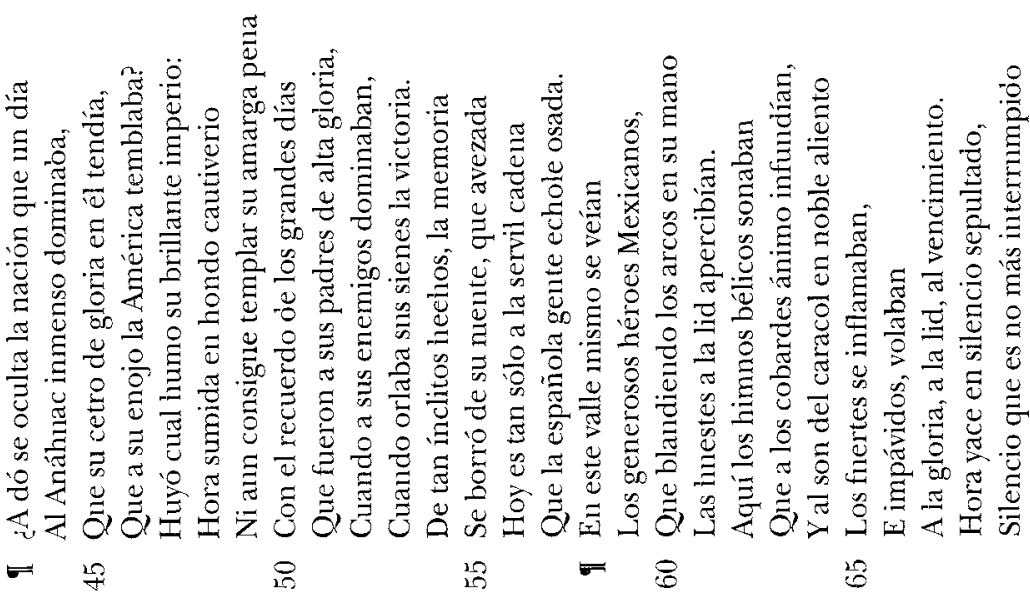

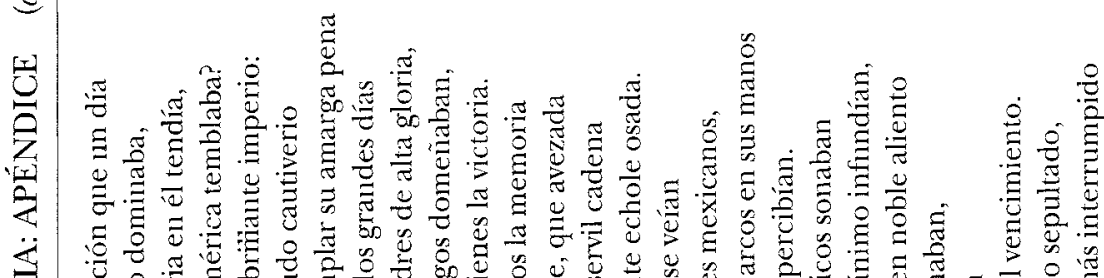

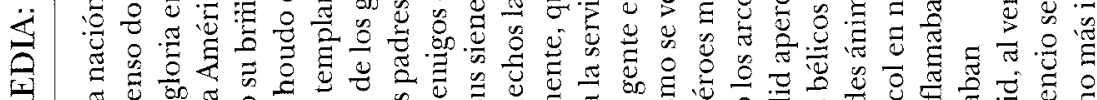

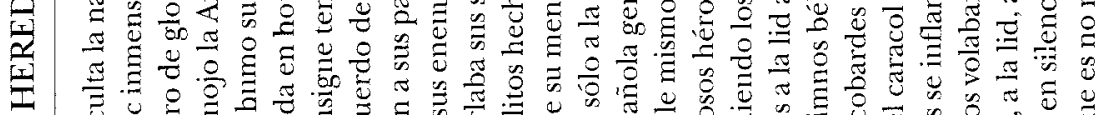

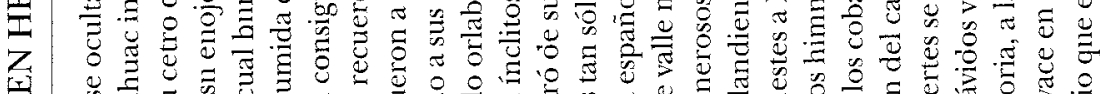
य)

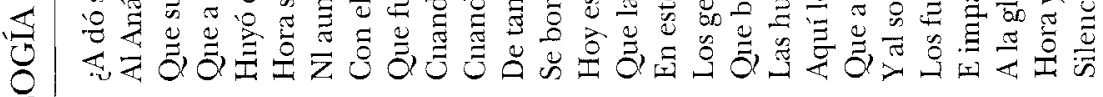

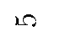

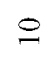$$
\text { 음 }
$$

จิ

ลิ

$\frac{n}{0}$

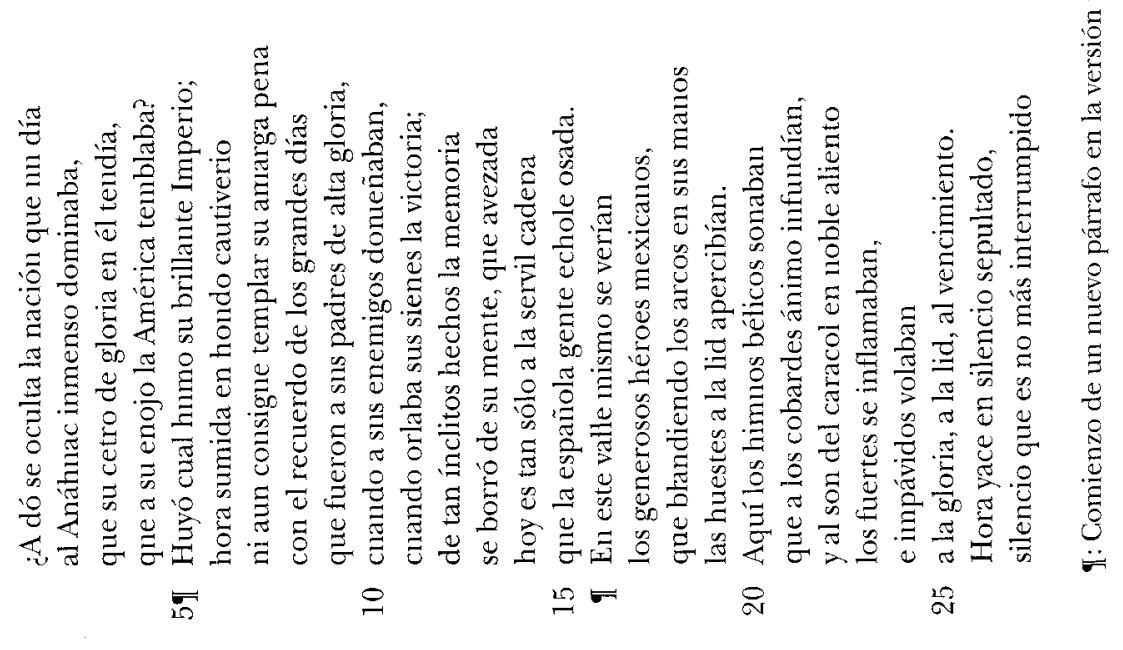



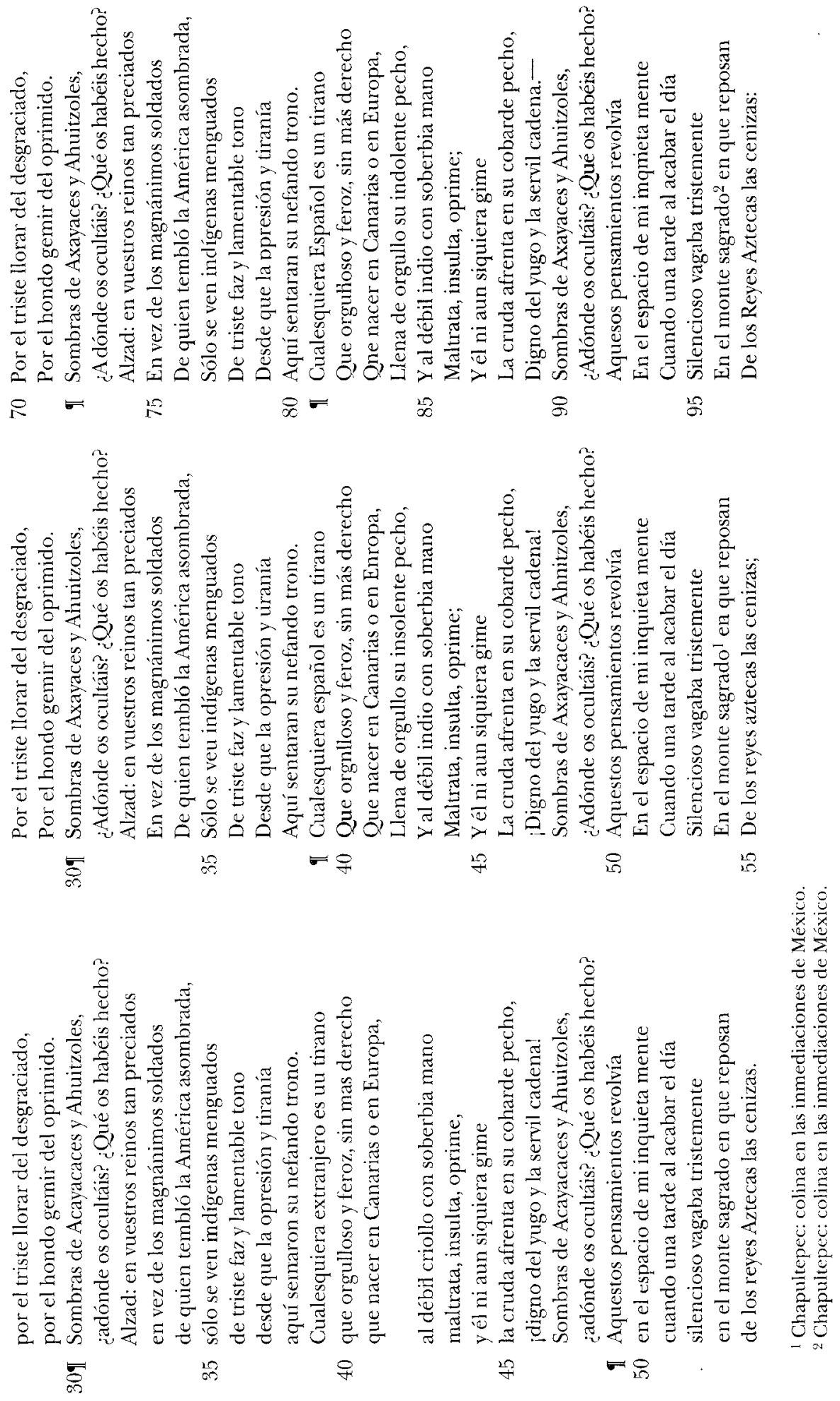
$\stackrel{8}{\substack{1 \\ \hdashline}}$

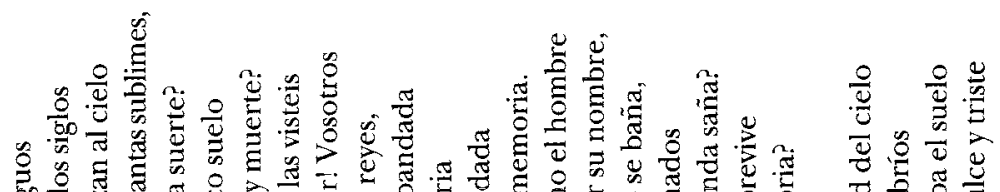

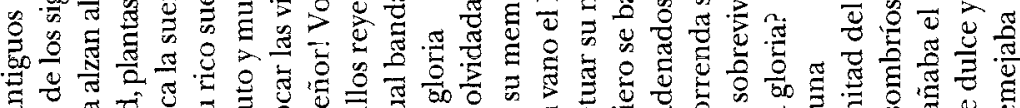

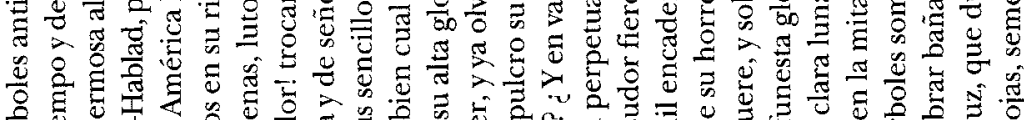

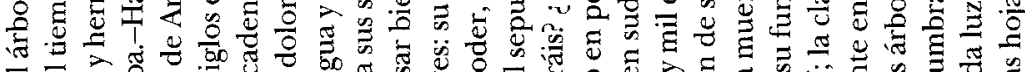

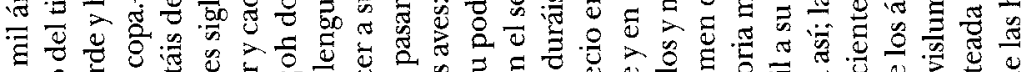
\&

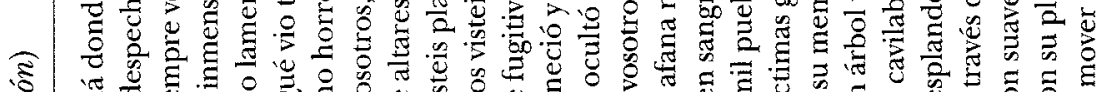

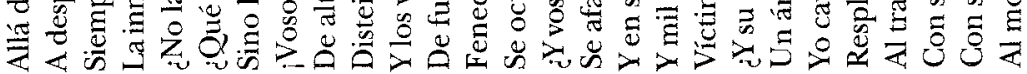

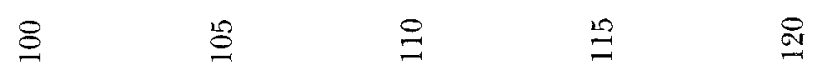

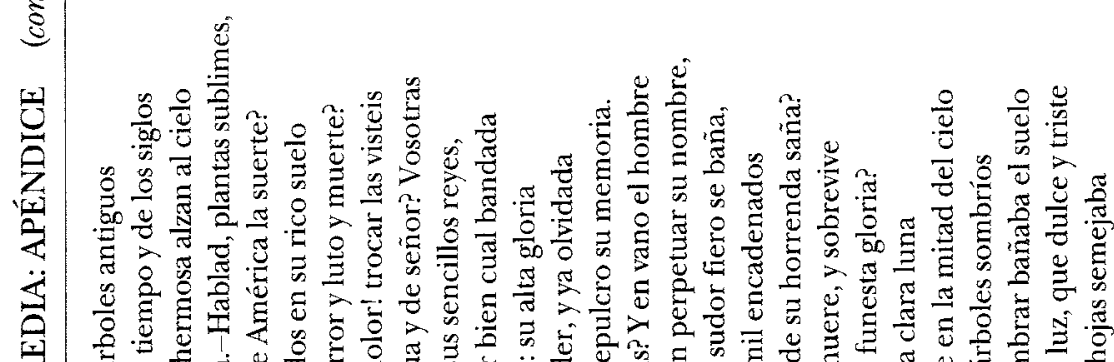

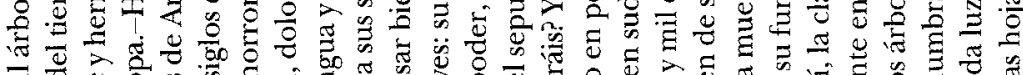

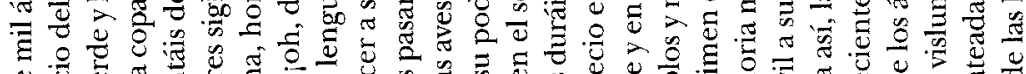

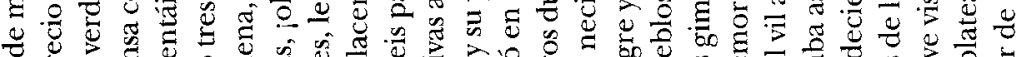

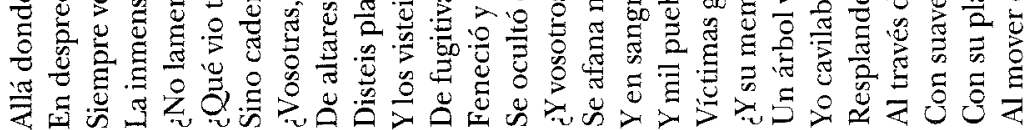

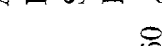

$$
8
$$

10

员

$$
19
$$

$\varnothing$

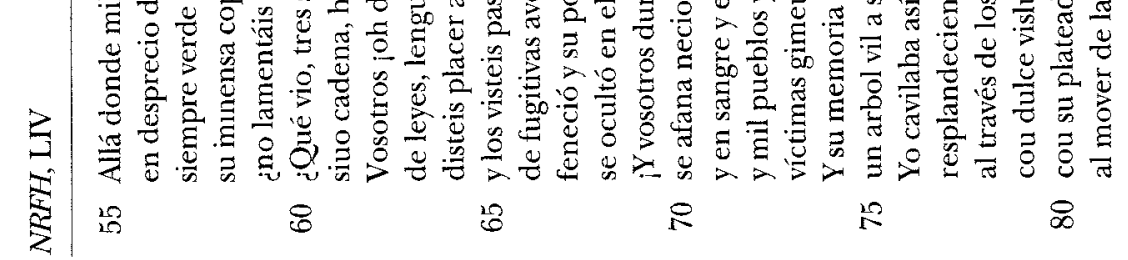




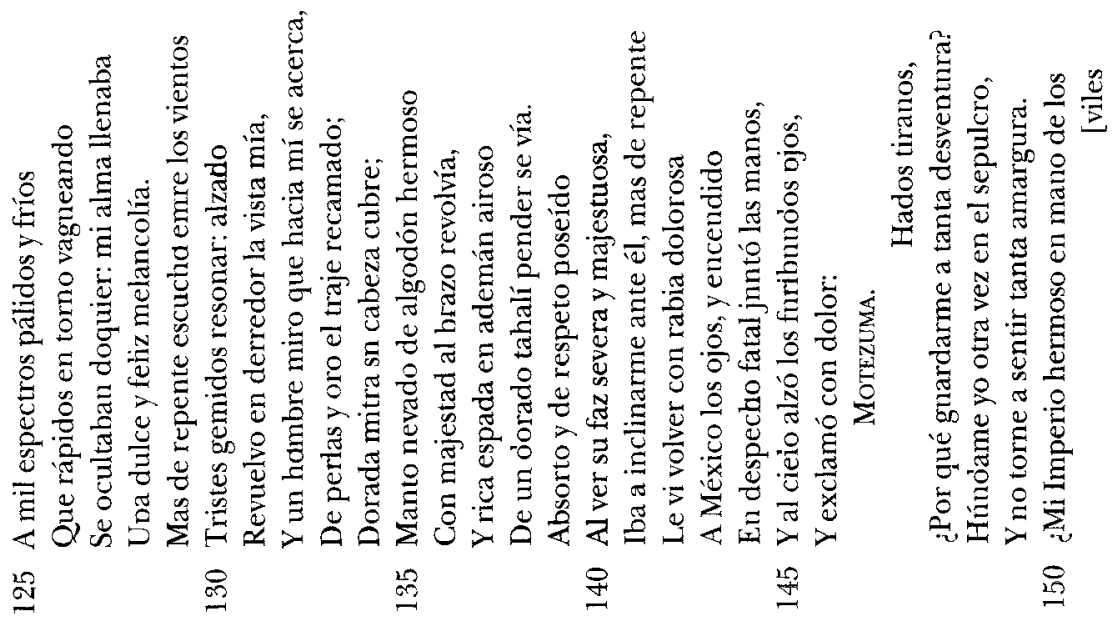
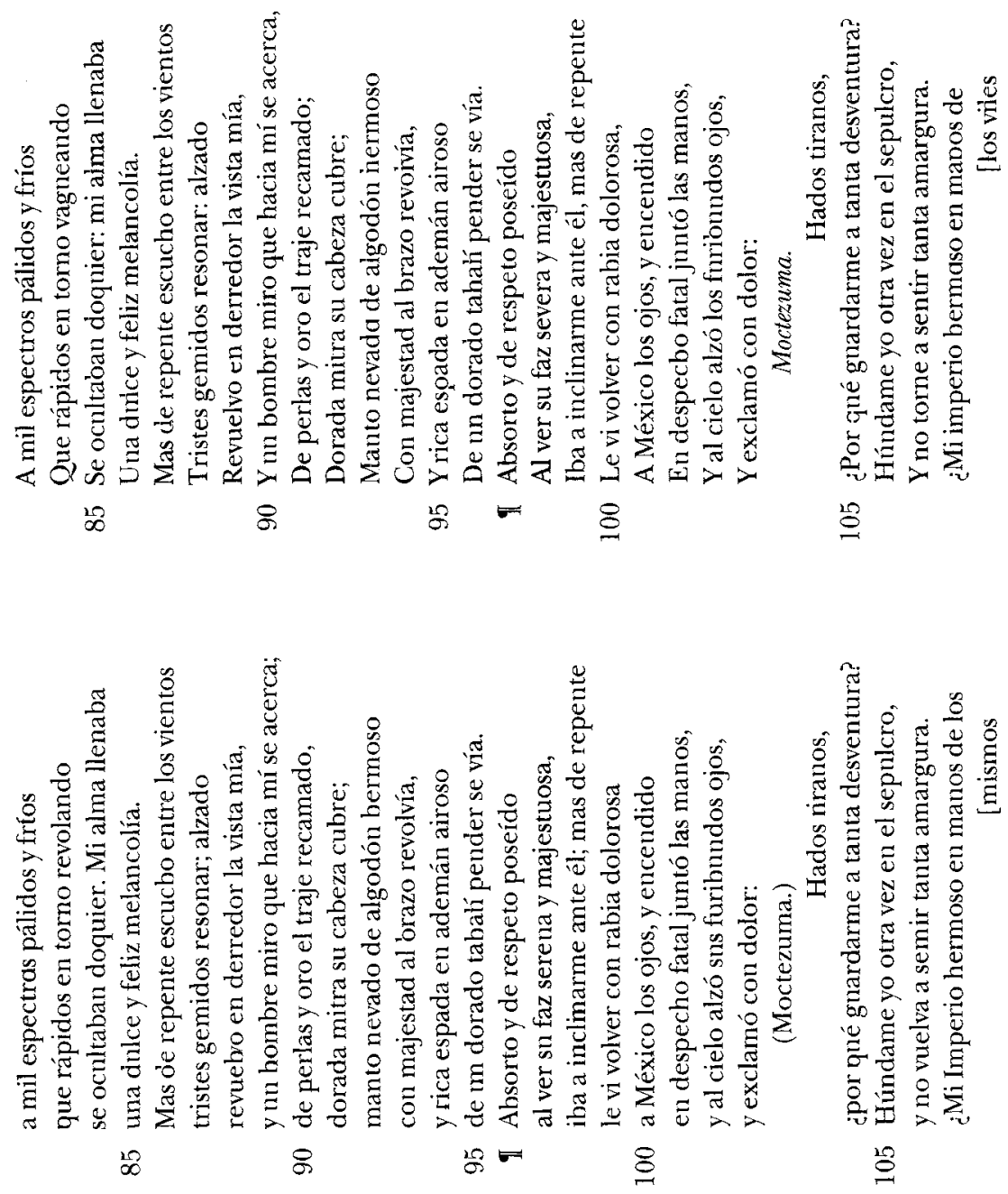
$\stackrel{0}{\stackrel{0}{5}}$

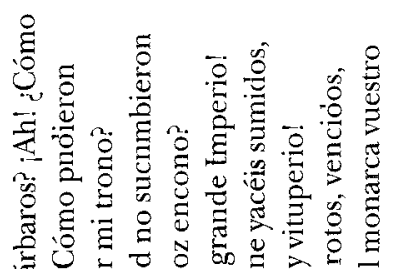

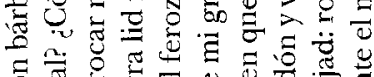

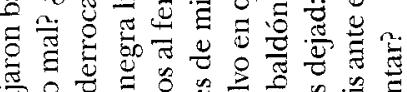

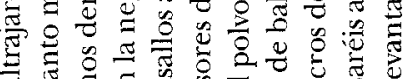

$\frac{\sqrt[3]{5}}{\sqrt[3]{5}}$

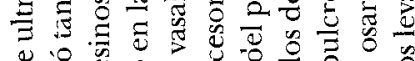

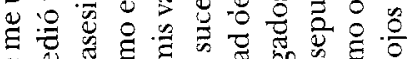

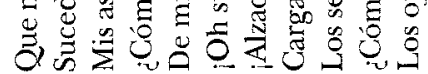<smiles>[CH]C</smiles>

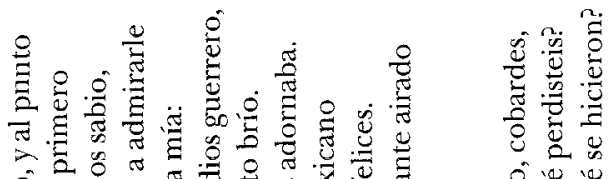

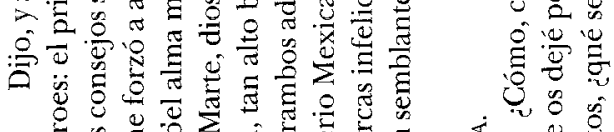

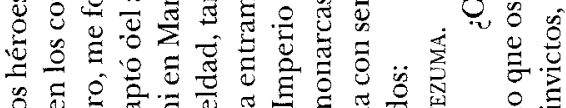

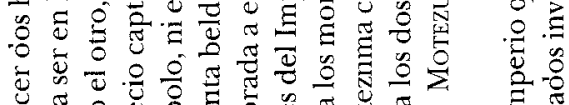

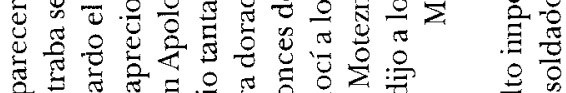

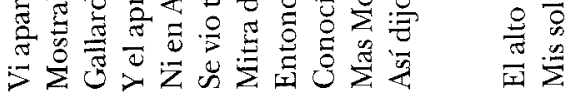

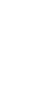

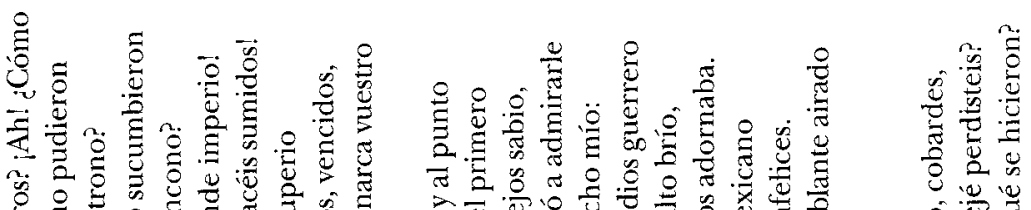

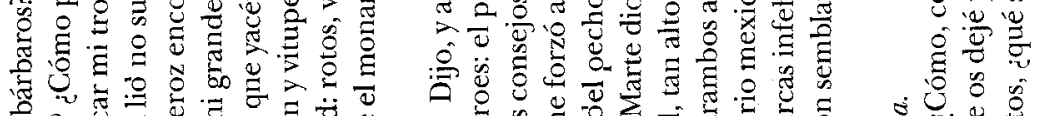

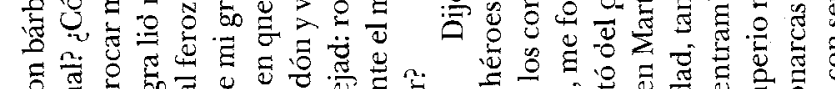

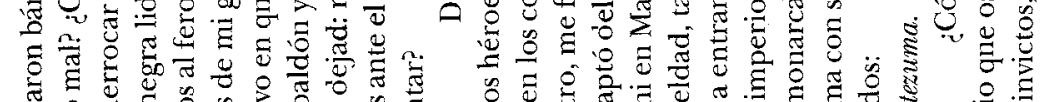

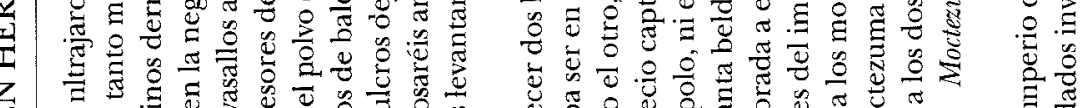
造

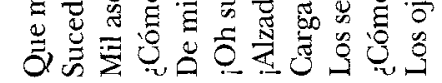

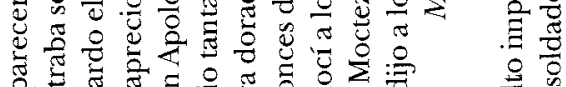

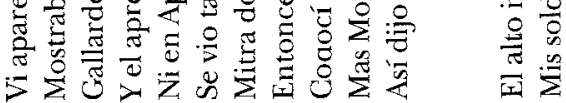

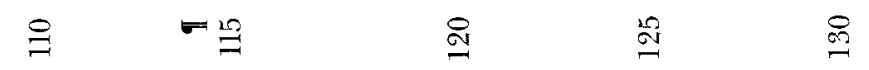

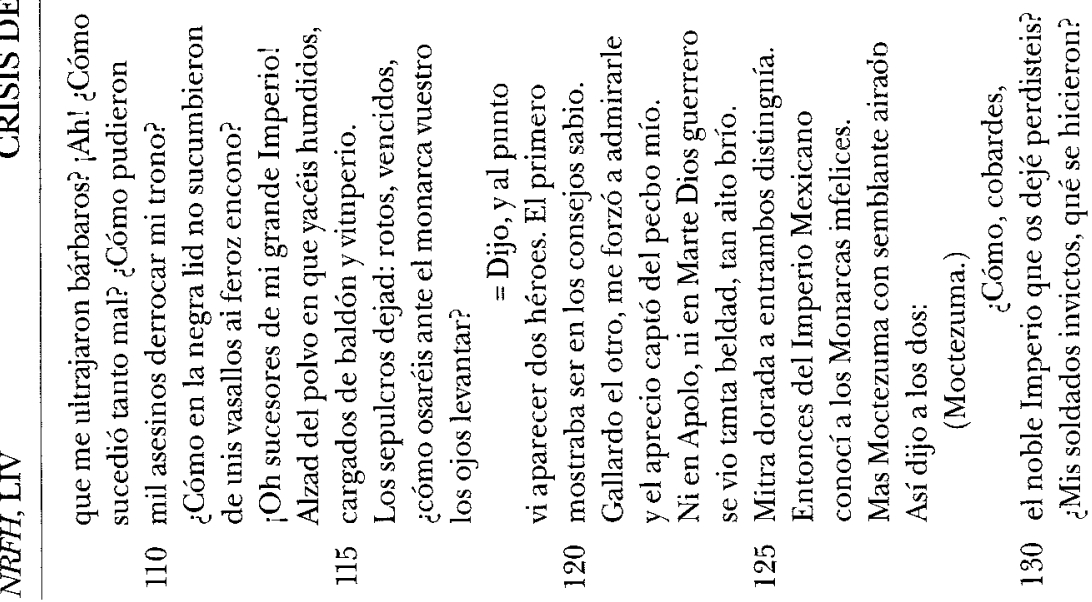




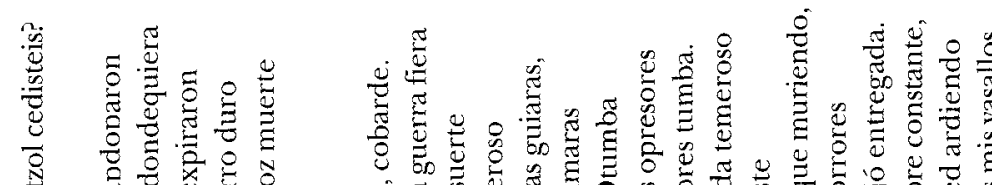

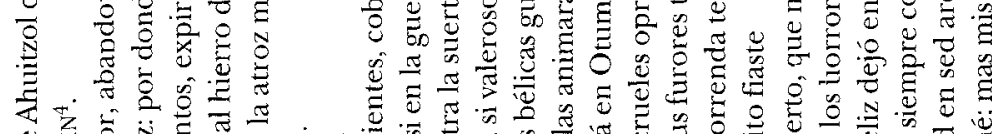

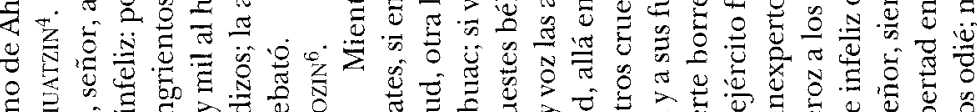

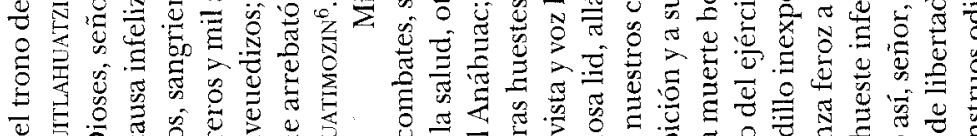

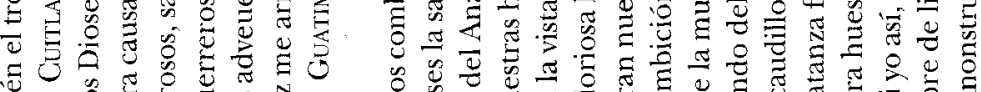

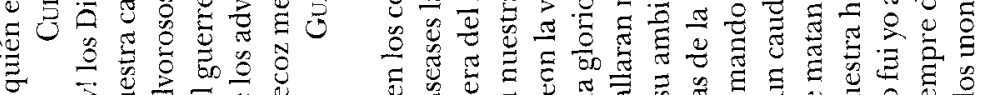

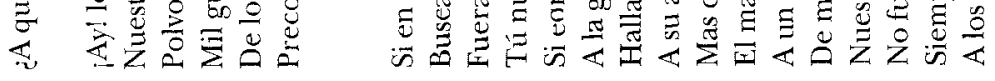

ts

$\stackrel{\infty}{\circ}$

$\stackrel{\infty}{\stackrel{\infty}{\infty}}$

品

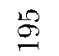

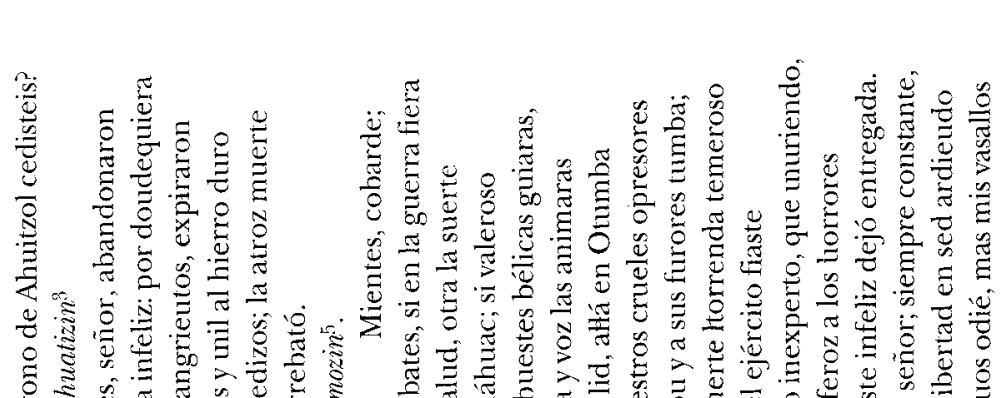
In⿴囗十)

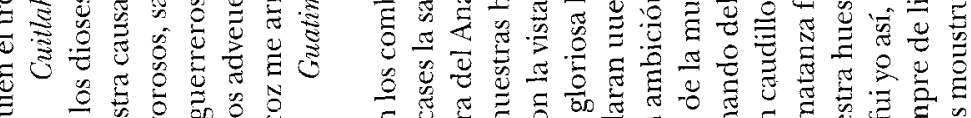
政 욱

桨

量

量

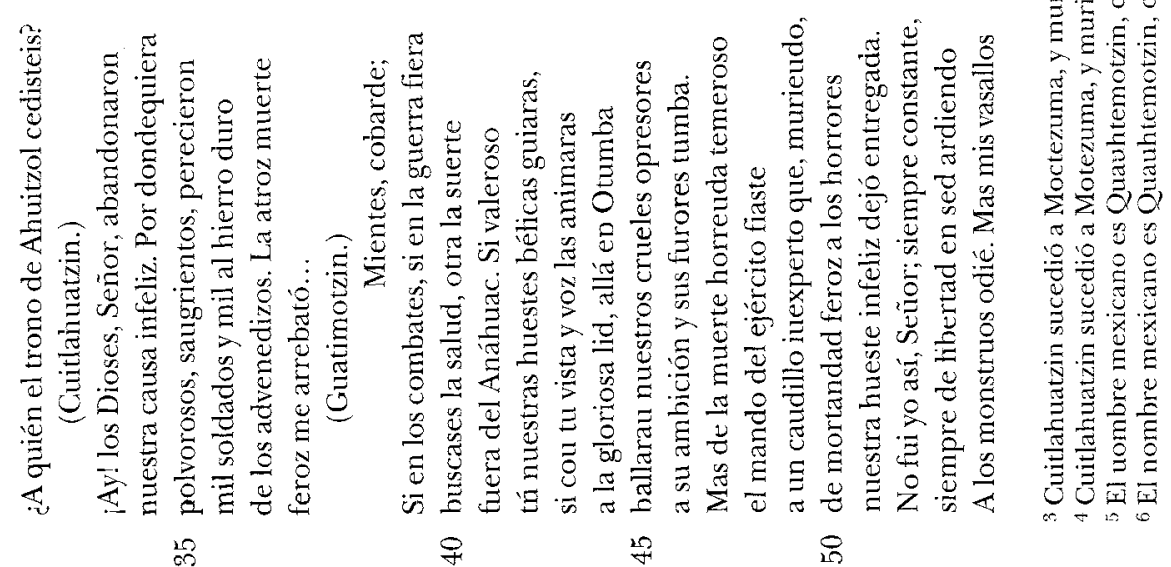

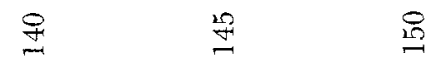




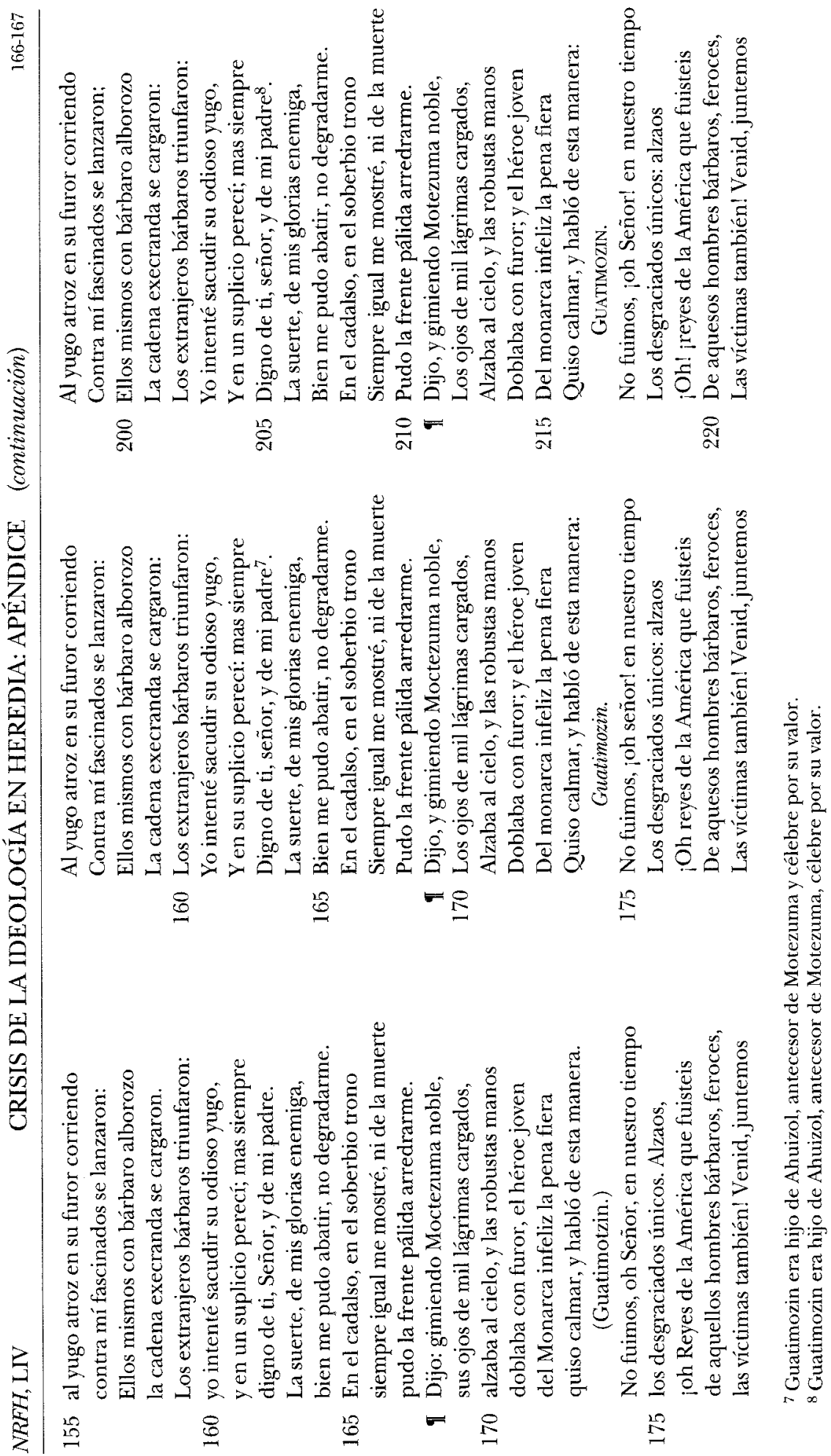




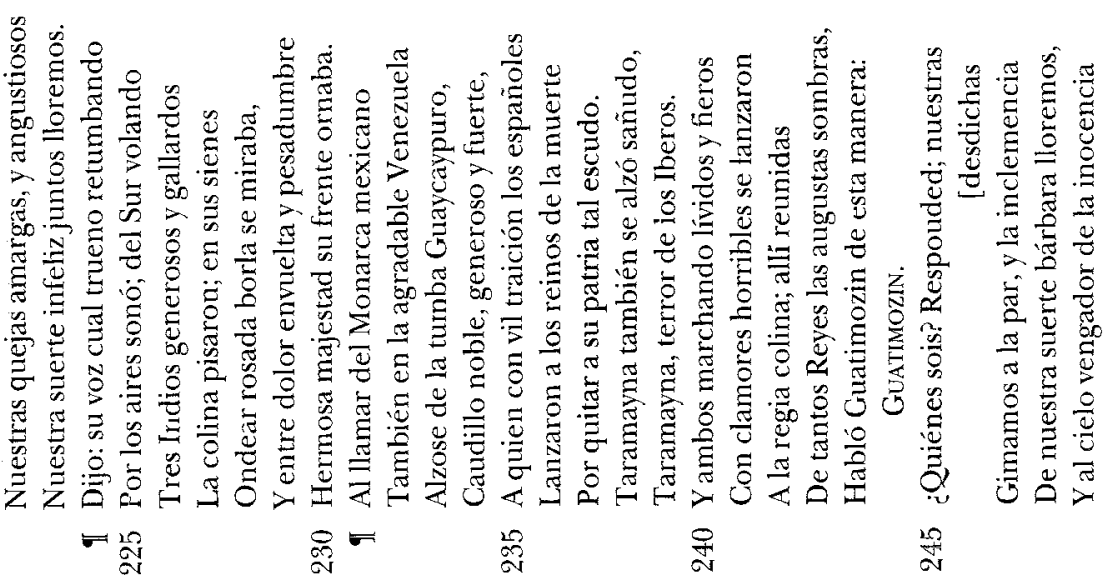

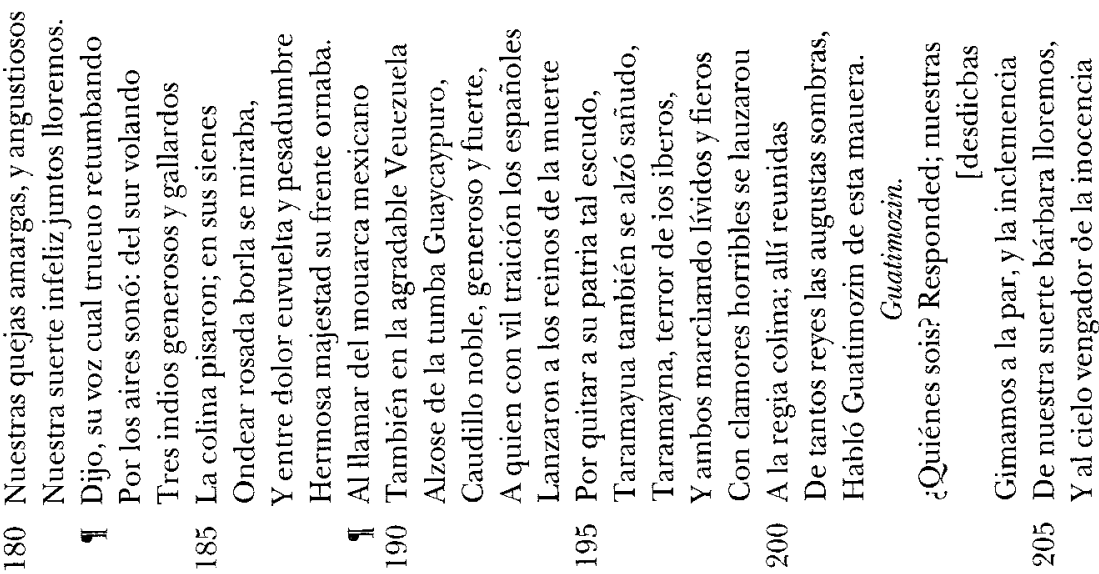

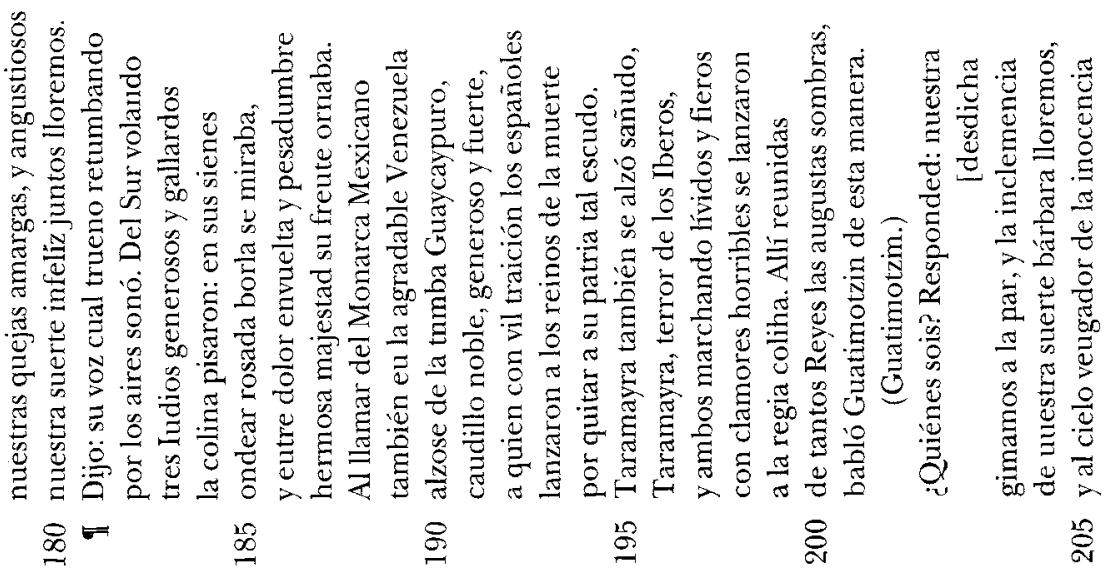




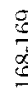

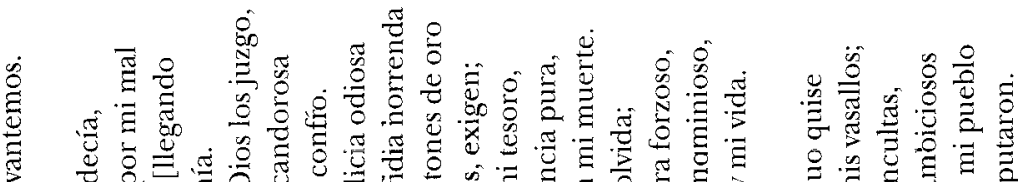

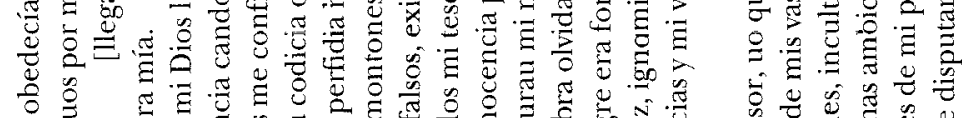

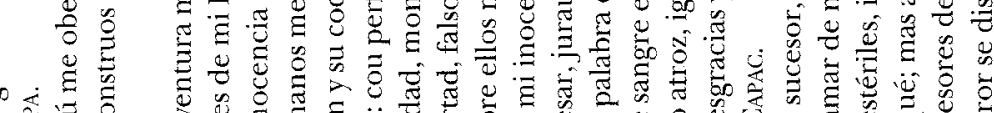

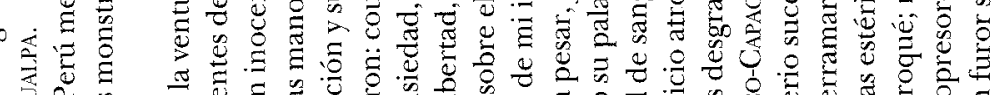

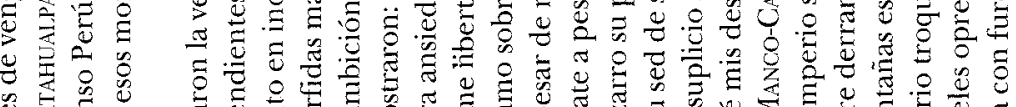

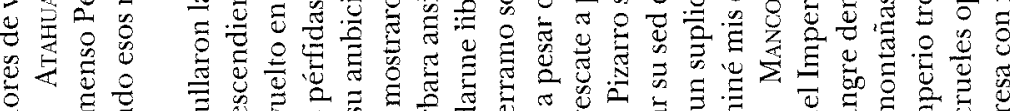

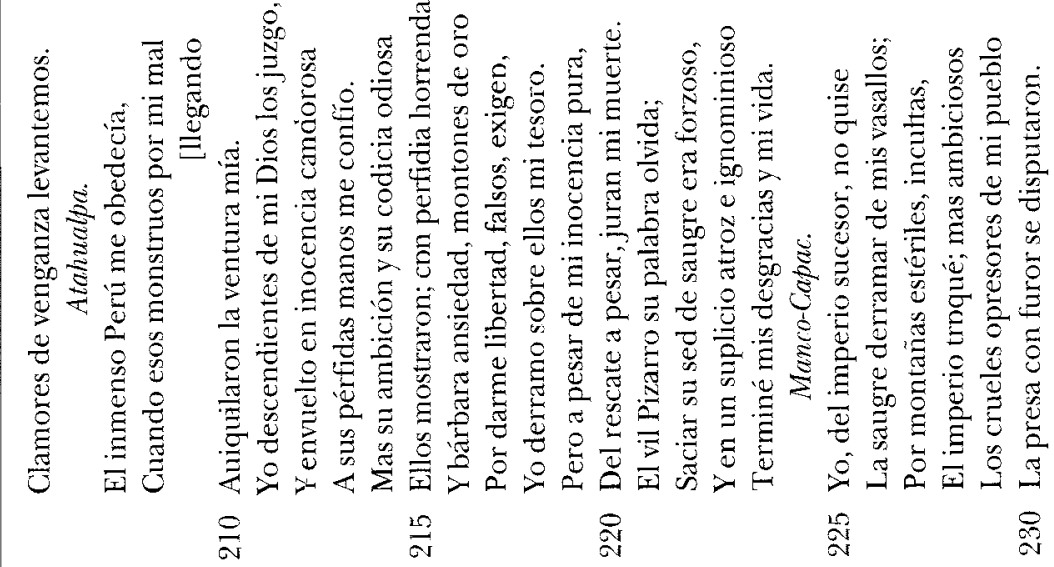

ปั

点

के

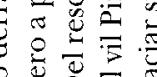

胥

8

过

o 2 品

i

尽

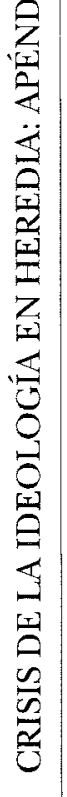

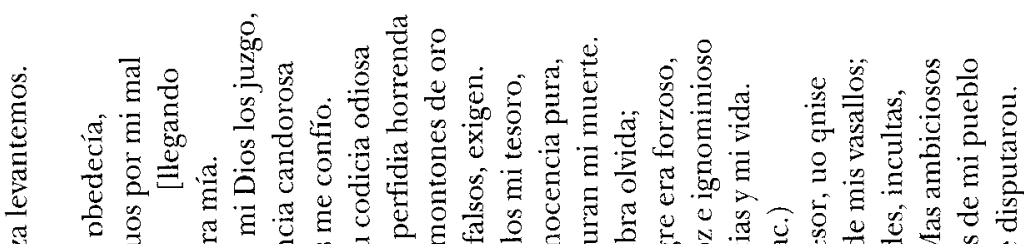

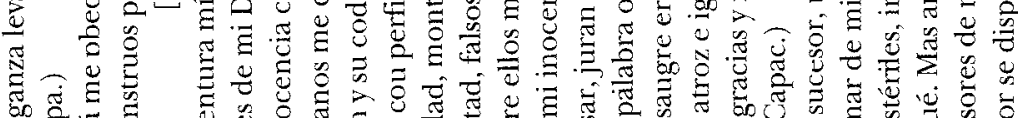

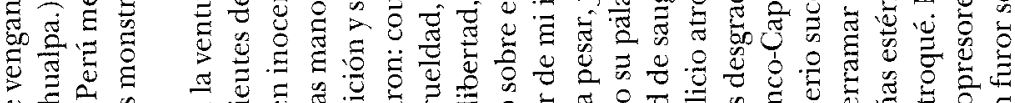

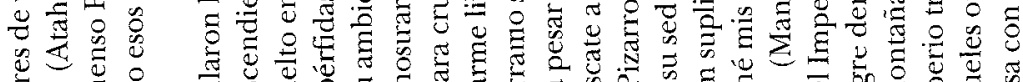

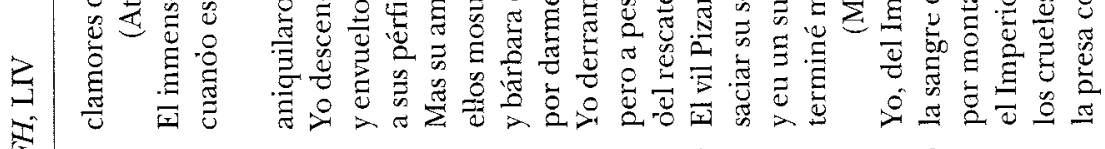
密 or $\frac{20}{2}$ ণ্ป 战 


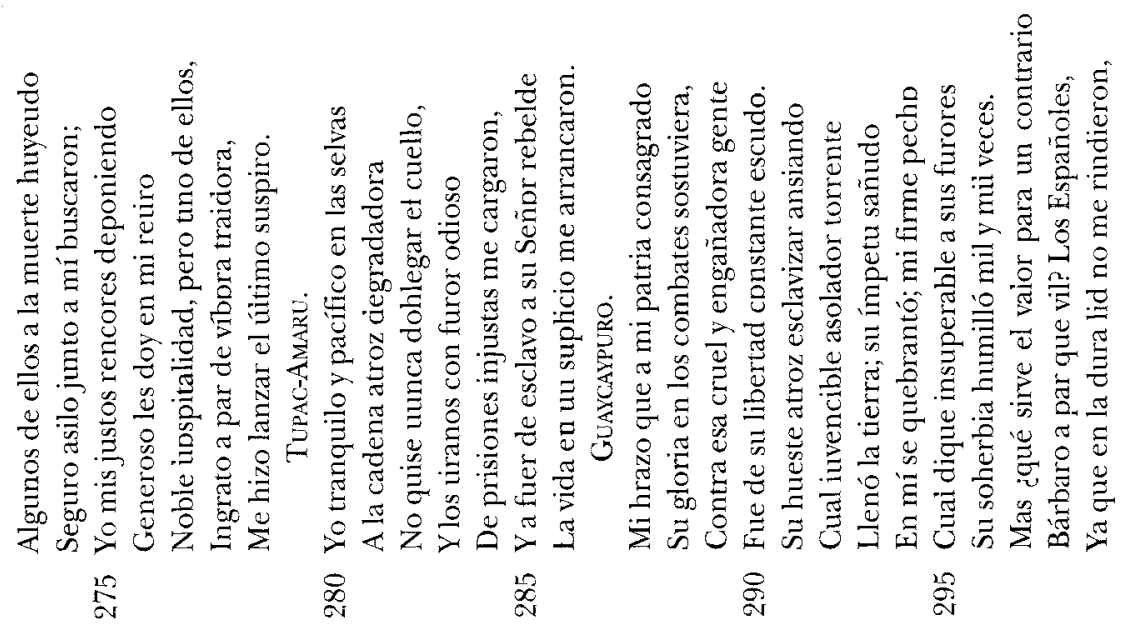

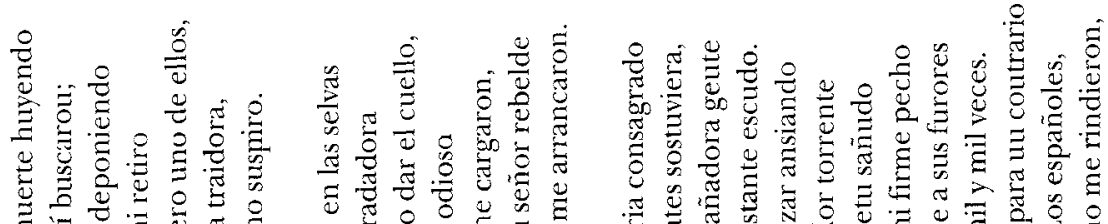

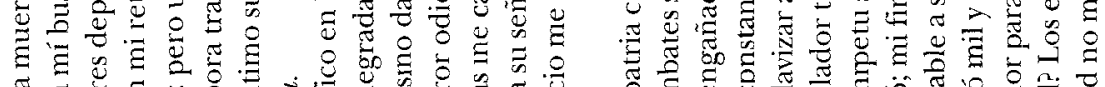
Mn

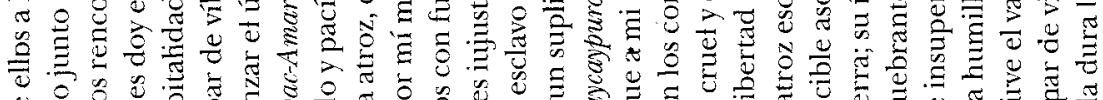

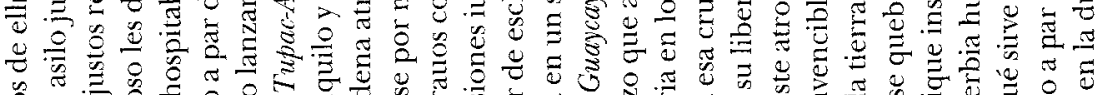

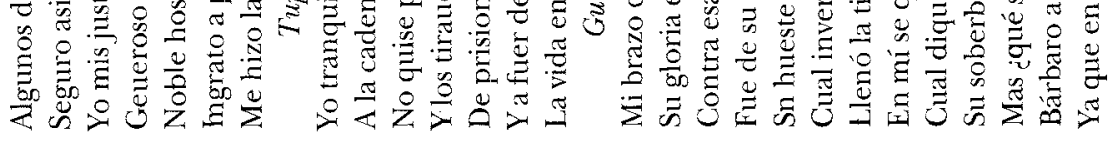

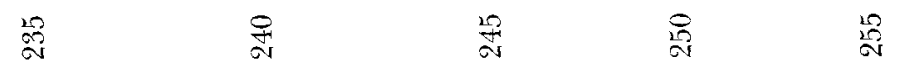

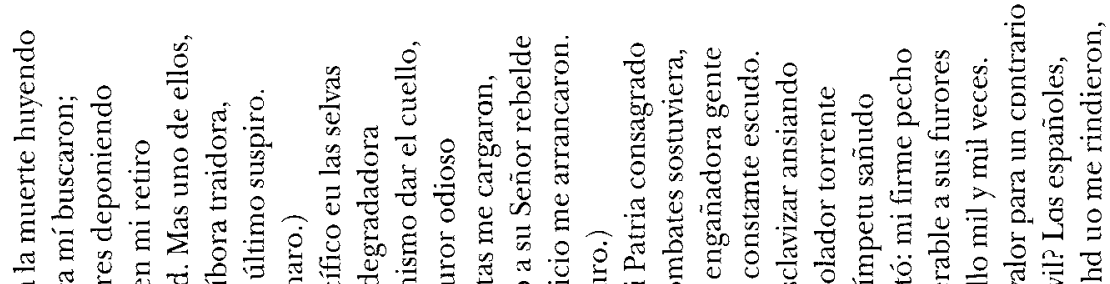

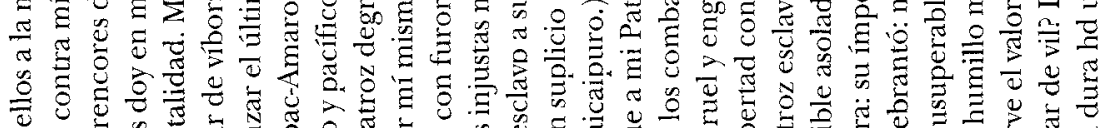
ప

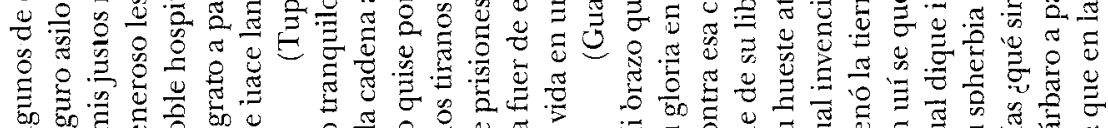

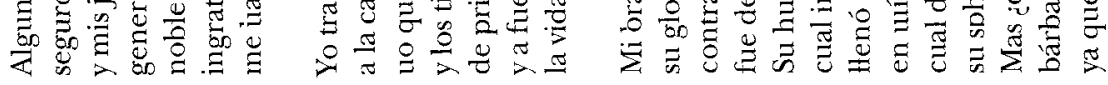
๙ิ

赵

윤

哭

ㅇํㅇ

总 


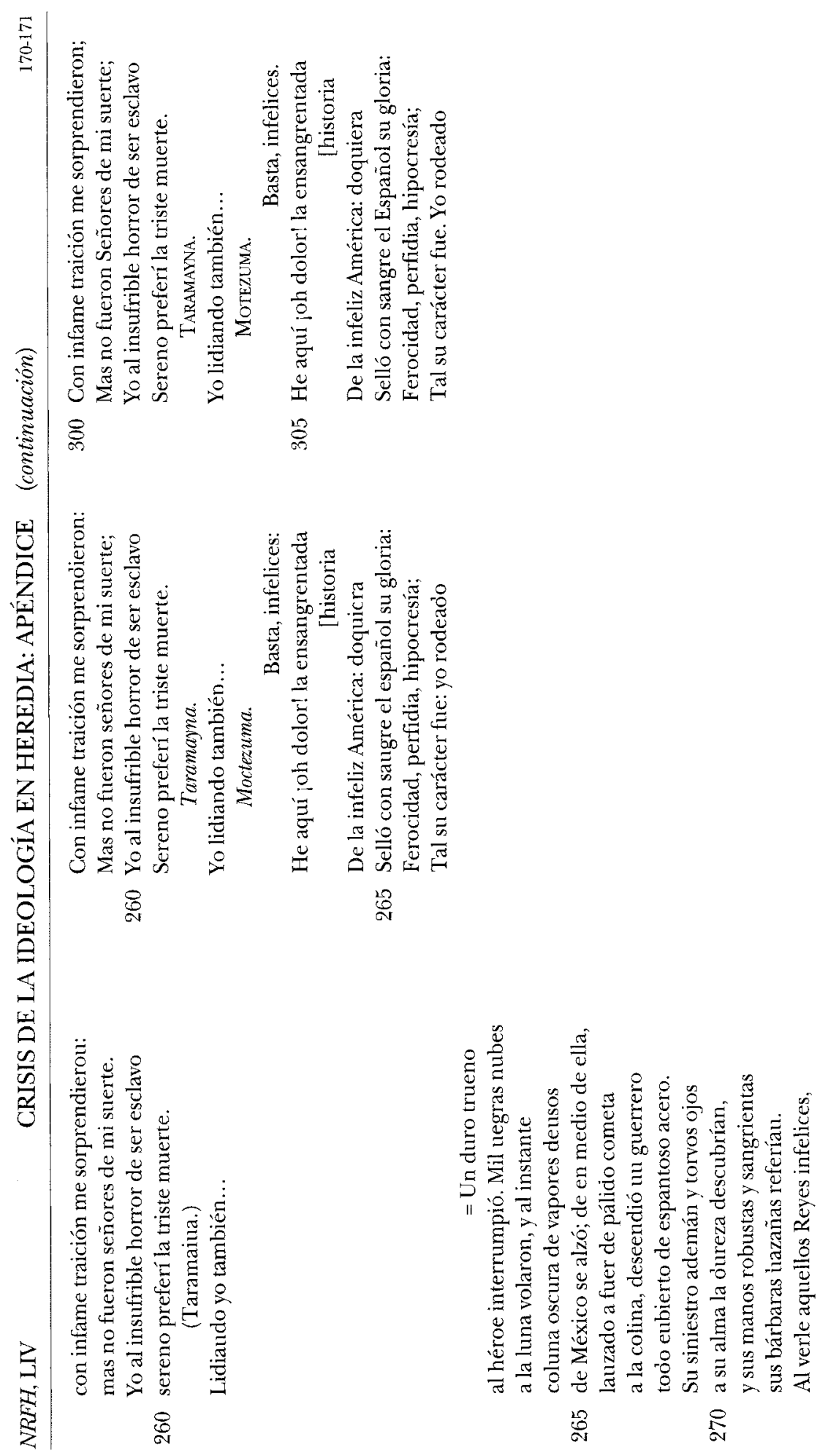




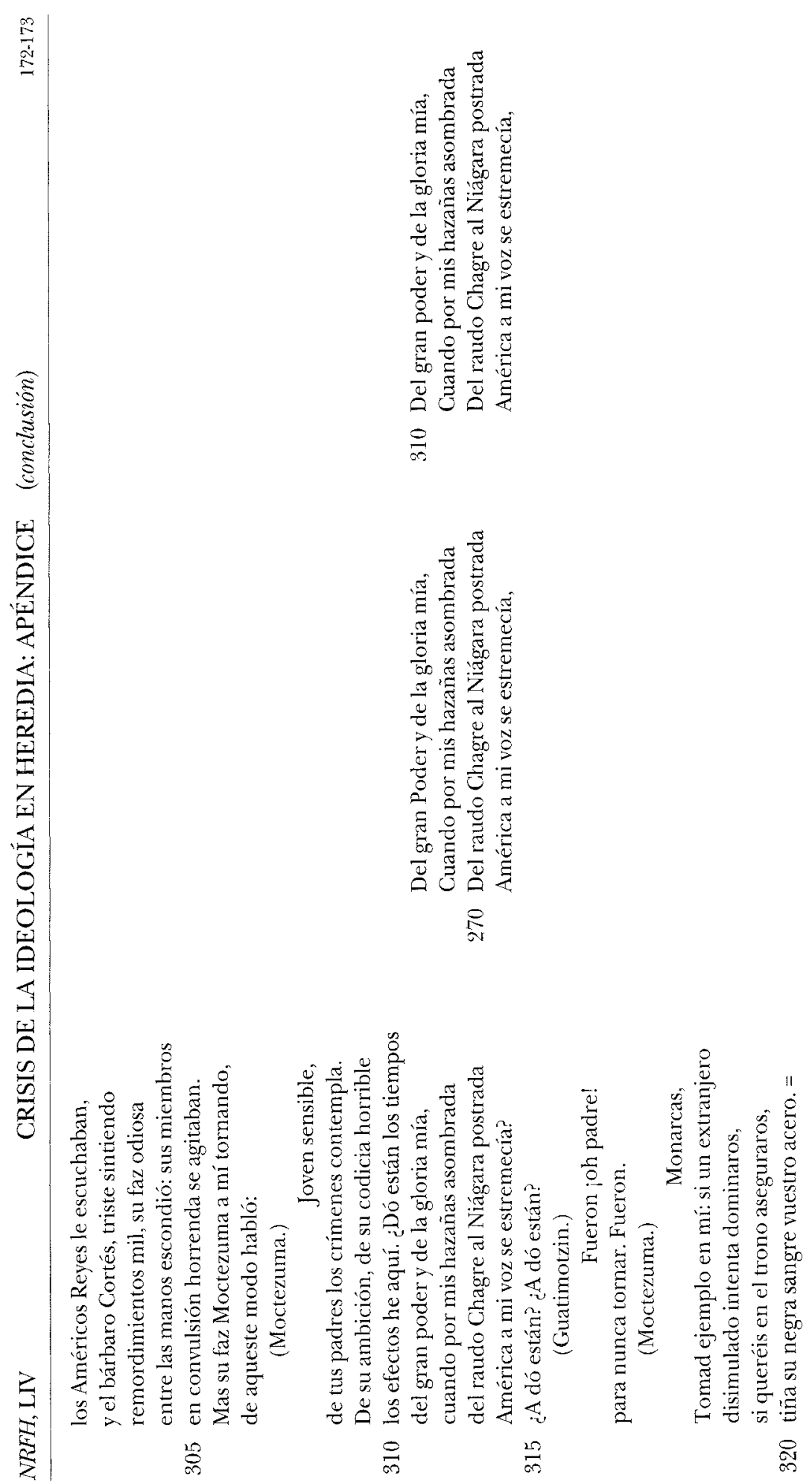




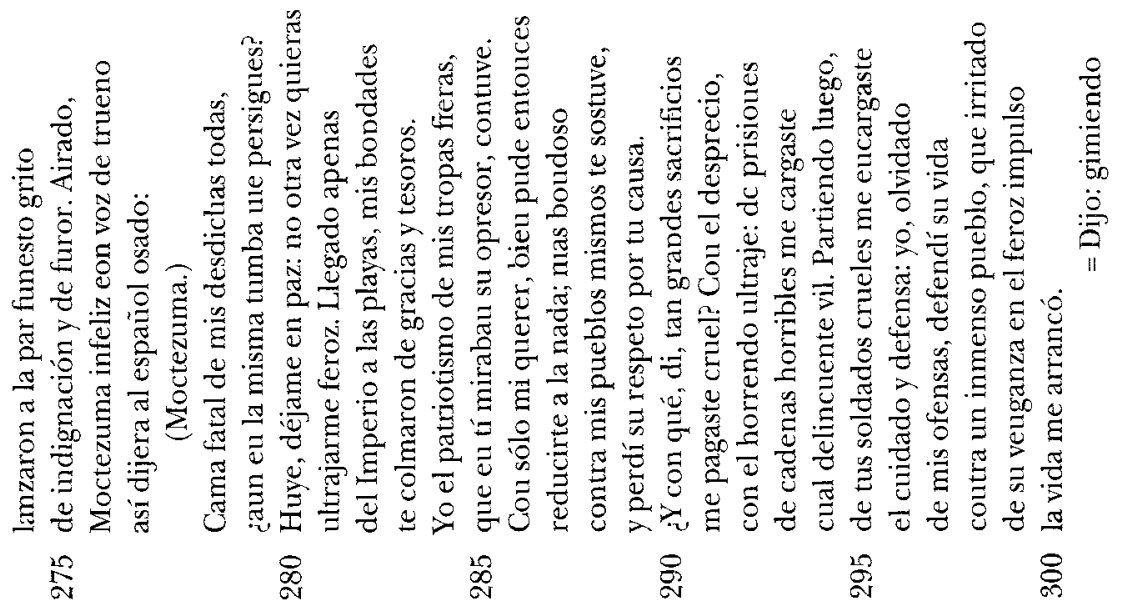



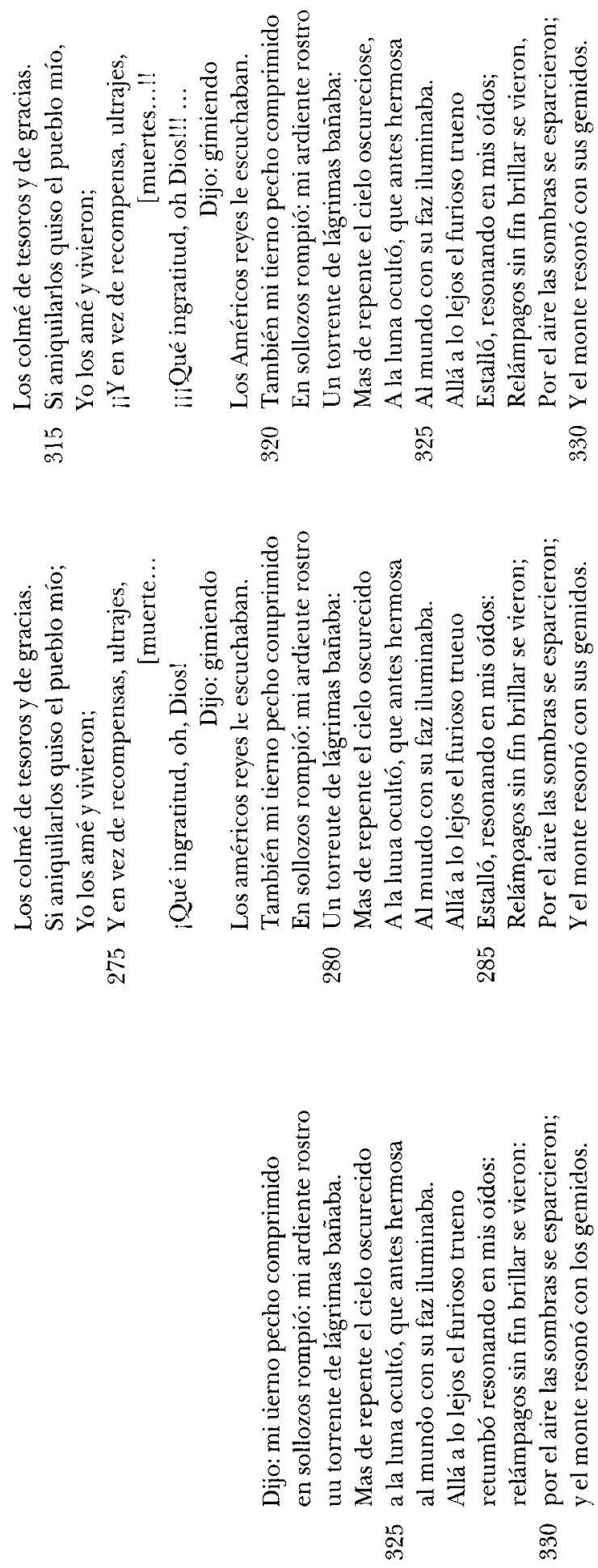
